\title{
Locke ve Rousseau'nun İnsan Doğası ve Toplum Düşüncesi
}

\author{
Olkan Senemoğlu
}

\begin{abstract}
Öz: Bu çalışma John Locke ve Jean Jacques Rousseau'nun insan doğası ve toplum anlayışına odaklanmaktadır. Sadece "insan doğası" ve "toplum" anlayışı ele alındığı için iki düşünürün düşüncesinde yer alan başka konular çalışmanın dişında tutulmuştur. Bu iki düşünürün insan doğası ve toplum anlayışlarından hareketle nasıl bir yönetim düşündüklerine ulaşmak bu makalenin temel hedefidir. Bu anlamda, bu iki filozofun insan doğası ve toplum anlayışlarının karşılaştırılması, onların sistemlerinin de anlaşılmasına olanak sunacaktır. John Locke insan doğasının eğitimle biçimlenebileceğini kabul eder, ama insanın özünün eğitim yoluyla tümüyle değişebileceğini düşünmez. İnsanlar tek başlarına yaşamaktansa topluluk halinde yaşamak gibi bir eğilime Tanrı'nın onları öyle yaratmasından dolayı sahiptirler. Diğer taraftan toplum içinde yaşamak insanın, yaşamını ve mülkiyetini saldırılardan korumasını sağlamaktadır. Devlet insanın yaşamını, mülkiyetini ve özgürlüğünü korumak için ortaya çıkar. Rousseau ise insanın herhangi bir doğal veya tanrısal özle topluluk içinde yaşaması gerektiğini düşünmez. Aksine insanın toplum içinde yaşamak için öncelikle belirli ihtiyaçlara sahip olduğunu düşünür. Rousseau'ya göre insan toplum içinde yaşamak için uyumlulaştırılmıştır. Rousseau, Genel İrade'ye ulaştıktan sonra insanın özgünlügünden ve farklılığından kaynaklanan hususları bir kenara bırakarak kamu otoritesiyle bütünleşmesini öngörür. Oysa John Locke, bireyin hiçbir şekilde doğal haklarından vazgeçmeyeceğini, gerekirse bireyi haklarından mahrum bırakan bir otoriteye karşı isyan edebileceğini savunur.
\end{abstract}

Anahtar kelimeler: Locke, Rousseau, insan, insan doğası, doğa, toplum, devlet, mülkiyet.

Abstract: This study focuses on human nature and society in the philosophy of John Locke and Jean Jacques Rousseau in a comparative perspective. Since it is limited with the debates on the concepts of "human nature" and "society" other elements in the philosophy of two thinkers have not been considered in this study. Each of these philosophers figures out how to achieve a government based on their understanding of human nature and society. The comparison of these two philosophers' understanding of human nature and society will provide opportunities to understand their whole political system. According to Locke, education can reshape human nature, but he does not believe that human nature can be fundamentally changed through education. Man has been created on the basis of living together with others in a society. Society and its political organization protect man's life, liberty and property. This is the reason d'etat of the state. Rousseau, on the other hand, does not think that man lives in a society because of his nature or a God-given character. Man, before living in society, has some specific needs. According to him, man has been harmonized to live in a human society in order to achieve his needs. Rousseau believes that man leaves behind whatever is particular to him and he goes to harmonize with the public authority once he reaches to the General Will. However, Locke believes that man's natural rights are unavoidable and man has right to revolt any government if it abstains man from his rights.

Keywords: Locke, Rousseau, human, human nature, nature, society, state, property.

\section{(C) İlmi Etüdler Derneği}

DOI: 10.12658/human.society.7.13.M0183

İnsan \& Toplum, 7(1), 2017, 187-221.

insanvetoplum.org 


\section{Giriş}

Aydınlanma çağı birçok gelişmenin yaşandığı bir çağdır: Güçlü kopuşların yaşanmasının yanı sıra var olan kurumların yeniden yorumlanması da söz konusudur. $\mathrm{Bu}$ çağ aynı zamanda yeni bir toplum, doğa ve insan algısının geliştirilmesiyle kendinden önceki çağlardan ayrılır. "İnsan her şeyin ölçütüdür" sözü yeniden yorumlanarak özümsenir. Böylece insan ve tercihleri belirleyici olarak ön plana çıkarken skolastik ve dogmatik kanılar göz ardı edilir. İnsanın Tanrı’ya inanma gibi bir özle doğduğu fikri eleştirinin odağına alınırken aydınlanma fikrinin kendisi de yavaş yavaş eleştiriye açılır. Elbette bütün bir siyaset felsefesi tarihinde insan doğası ve topluma dair fikirler bulmak mümkündür ama bu çağ birçok yönden diğer çağlardan ayrılmaktadır. Aydınlanma çağı düşünürleri olarak Locke ve Rousseau'ya değinmeden önce kısaca bu iki filozofa gelinceye kadar, insan doğası ve topluma dair ne tür fikirler ileri sürülmüş kısaca bakalım.

Antik yunan düşüncesinden başlayacak olursak: Platon'a göre herkesin mayası farklıdır. "Tanrı, aranızdan önder olarak yarattıklarının mayasına altın katmıştır. Onlar bunun için baş tacı olurlar. Yardımcı olarak yarattıklarının mayasına gümüş, çiftçiler ve öbür işçilerin mayasına da demir ve tunç katmıştır" (Platon, 1975, s. 105).

Böylece Platon herkesin kendi mayasına uygun işleri yapmasını ister ve toplum anlayışını da bu doğrultuda oluşturur. Kendi mayasına göre işlerde uğraşması gereken inanların doğasını ortaya çıkaracak olan şey eğitimdir. Sadece "Gymnasium"ların, atıcılık ve okçuluk eğitimlerinin yanı sıra "babası isteyen okula devam eder, istemeyen eğitimi bırakır' diye bir şey söz konusu olamaz, ayrıca 'her erkek adam' babasından çok devletin malı olduğu için, elden geldiğince zorunlu olarak eğitim görecektir" (Platon, 1998, s. 23). Aristoteles de hocası gibi düşünür. Ona göre doğa bir amaç, bir ereksel nedendir (1997, s. 59) onun için özgür insan kendi ereğini kendi içinde taşıyan bir başkası için var olmayan insandır (1985, s. 88). Ayrıca Aristoteles'e göre, insan doğal yapısı gereği toplumsal bir varlıktır (1997a, s. 10) ve "Hiç kimse bütün iyilere sahip olmayı tek kendisi için tercih etmese gerek, çünkü insan toplumsal, doğası gereği birlikte yaşamaya yatkın"dır (1997b, s.193). Ayrıca Aristoteles'e göre yöneten ve yönetilen kişi de doğası gereği belirlenmiştir. “Gereken şeyleri zekâsıyla önceden görebilen bir kimse, doğaca yönetici ve efendidir, oysa beden gücüyle bunları yapabilen bir kimse doğaca köledir, yönetilenlerden biridir" (Aristoteles, 1975, s. 8).

Agustinus'un insan doğası anlayışına bakacak olursak, ona göre dünyadaki kötülüğün kaynağı Tanrı değil bizatihi insanların kendisidir ve insanların cüzi iradelerinden gelmektedir (Agustinus, 1999, s. 17). Farabi'ye göreyse, varlıklar çeşitli ka- 
rışımlardan meydana gelmiştir ve insan; bitkiler, hayvanlardan sonra en müstesna birleşimlerden oluşmuştur (2001, s. 47). Ayrıca insan tabii olarak insani bir akla sahiptir ve bu özelliğiyle diğer varlıklardan farklıdır (2001, s. 66). Farabi de Aristoteles gibi düşünür; ona göre "Her ferd, tabiatındaki mükemmelleşme ihtiyacını, ancak muhtelif insanların -yardımlaşma maksadıyla- bir araya gelmeleriyle elde edebilir" (2001, s. 79). Bir diğer İslam düşünürü İbn-i Haldun'a (2004) baktığımızdaysa o, insanı, fıtratıyla açıklamaktadır:

\begin{abstract}
"Allah insanı, ancak beslenerek yaşamını sürdürebilecek bir tabiatta yaratmış, fitri olarak onu beslenmeye yönlendirmiş ve kendisine beslenmek için gerekenleri yapacak bir donanım vermiştir. Ancak birey olarak tek bir insanın gücü, beslenme ihtiyacını karşılama ve yaşamını devam ettirecek maddeleri bulma işinde yetersiz kalır. Örneğin insanın günde sadece bir miktar buğdayla yaşamını sürdürebileceğini kabul etsek bile, yine de o buğdayın öğüülüp un haline getirilmesi, hamur yapılması ve pişirilmesi gibi aşamalardan geçmesi gerekiyor. Bu üç işi yapabilmek için ise birçok eşya ve alete; bu eşya ve aletler için de demircilik ve çömlekçilik gibi ustalıklara ihtiyaç vardır" (s. 79).
\end{abstract}

Rönesans dönemine bakacak olursak, insan doğası tartışmalarının orada da devam ettiği görülmektedir. Machiavelli'ye göre, insan genellikle nankör, değişken, içten pazarlıklı, korkak ve çıkarcıdır (1994, s. 106). Bundan dolayı böyle insanları yönetecek olan Prens'e ögüt verirken “Onlar iyilik ettiğin sürece hepsi seninledir; gerekmedikçe kanlarını, mallarını, canlarını ve çocuklarını sana sunarlar ama bir gerekmeye görsün hepsi senden yüz çevirirler” demektedir (1994, s. 106). Böyle der çünkü Machiavelli'ye göre, "Eğer insanların tümü iyi kimseler olsalardı yerilesi bir öğüt olurdu bu; ama nasıl ki tümü de küçük adamlardır ve sana verdikleri sözleri tutmazlar, senin de onlara verdiğin sözde durman gerekmez (1994, s. 110).

Bacon ise insan doğasının sertliğini kuralların ve öğütlerin azaltacağını ama yalnızca alışkanlıkların onu değiştirip sıkıya sokabileceğini düşünür (2006, s. 157). Fakat diğer taraftan hiç kimsenin yaratılışını yenebileceğine inanmadığını da söyler. Çünkü "o uzun süre derinlerde gizlenir de, elverişli bir durum bulur bulmaz gene ortaya çıkıverir" (Bacon, 2006, s. 158). Fakat Bacon (2012) yine de insanın değişebilir veya değiştirilebilir bir doğaya sahip olduğunu söyleyerek insanın doğasının sabit mi değişebilir mi olduğunu net bir şekilde yanıtlayamaz:

"Herkes (insan ırkında ortak olan hatalara ek olarak) ya kendine özgü ve tek olan yaratılışından dolayı; ya eğitimi ve diğer kişilerle olan ilişkilerinden dolayı ya okuduklarından dolayı ve bireyin hayranlık ve saygı duyduğu kişilerin otoritelerinden dolayı ya zihinde meydana getirilen farklı etkilerden dolayı önceden işgal edilmiş ve önceden yerleştirilmiş ya da düzenli ve sakin bir şekilde vb. olduğu için, tabiatın ışığını durduran ve bozan kendi bireysel mağarasına sahiptir. Öyle ki, insan ruhu (genel yaratılışına göre) değişebilen bir özelliğe sahiptir, karışıktır ve sanki şans eseri harekete geçirilmiştir” (s. 127). 
Locke ve Rousseau'dan önce üzerinde duracağımız bir diğer düşünür ise Thomas Hobbes'tur. Hobbes, insan doğası tartışmalarını iki çıkarım üzerine kurar: "Herkes ortak mülkiyeti kendisi kullanmak ister; ikinci ise tüm insanları doğadaki en büyük kötülük olan vahşi bir ölümden kaçınmaya yönelten doğal akılla ilgilidir" (2014, s. 4). Bundan dolayı Hobbes (2014) insanın sürekli bir korku halinde olduğunu ve bu durumun göz önünde bulundurulması gerektiğini söyler:

\footnotetext{
"Yasaların olduğu ve suç işleyenler için cezaların konduğu devletlerin içinde bile, yurttaşlar kendilerini savunacakları silahlar olmadan seyahat etmezler veya diğer yurttaşlara karşı kapılarını sürgülemeden ve hatta evdeki hizmetçilere karşı sandıklarını ve kutularını kilitlemeden yatağa girmezler. İnsanlar birbirlerine karşı besledikleri evrensel güvensizliği daha açık nasıl ifade edebilirler?" (s. 11-12).
}

İnsanın doğasında Hobbes'a göre üç temel kavga nedeni vardır: "Birincisi, rekabet; ikincisi, güvensizlik; üçüncüsü de şan ve şeref” (2007, s. 94). Fakat insanlar arasındaki bu kavga nedenlerinin olması, insanların doğa tarafından kötü yaratıldığı anlamına gelmez. Hobbes'a göre kötü insan, daha çok gürbüz bir oğlan çocuğuna benzer veya çocukça bir akla sahip bir insana (2014, s. 13). "Öyleyse" diyor Hobbes, "doğadan aldıkları bir terbiye ve akıl yürütmeden mahrum oldukları için insanlar doğa tarafından kötü yaratılmıştır denilmedikçe, insanların arzu, korku, kızgınlık ve benzeri hayvani duyguları doğadan aldıklarının ama yine doğa tarafından kötü yaratılmadıklarının kabul edilmesi gerekir" (2014, s. 13). Ayrıca Hobbes, insanın toplumsal bir varlık olduğu fikrini de eleştirir. İnsan bir arada yaşamak için birbirine karşı sevgi beslemez. "İnsan diğer insanlara karşı doğal bir sevgi besleseydi, herkesin herkesi insan olduğu için eşit derecede sevmemesi veya arkadaşlığını tercih etmeleri için hiçbir neden olmazdı. Öyleyse doğa gereği, biz onların arkadaşlğını değil ama onlardan gelecek şan ve yararın [commodum] peşindeyiz" (Hobbes, 2014, s. 22).

İnsanın ve toplumun ne olduğu tartışılırken devletin niteliğinin ne olması gerektiği de tartışmalar arasındadır. Bu anlamda nasıl bir devlet olması gerektiği, insan ve toplum algısıyla bağlantılı olarak ele alınır.

Birçok devrime fikir sahipliği yapmış olan aydınlama çağı, ilk büyük dönüşümünü İngiltere'de yaşamıştır. Zira İngiltere'de eşitlik, özgürlük, toplumsal sözleşme gibi kavramların yanı sıra, akla dayalı evrensel bir bilim ve kültür yaratmanın yolları da aranmaktadır. Eskinin içinde yeninin filizlendiği bu dönem John Locke ile önemli bir başlangıç yapmaktadır. Aydınlanma çağı kimi filozoflar tarafından olumlanırken kimileri tarafından da eleştirilmiştir. Bu anlamda Locke, aydınlanma çağını belirli dönüşümler istemekle birlikte olumlarken, Jean-Jacques Rousseau, artık aydınlanma insanının yaşamakta olduğu dönüşümün olumlanamayacak bir seviyeye geldiğini düşünür ve aydınlanma aklını eleştirir. 
Locke ve Rousseau'ya gelinceye kadar birçok filozof görüldüğü üzere insan doğası ve toplum üzerine farklı farklı açıklamalarda bulunmuştur. Bu görüşler genel olarak insan doğasını insanın dışında bir hakikate dayandırarak açıklamaktadırlar. Hobbes'la birlikte kırılmaya başlayan bu düşünce Locke ve Rousseau ile birlikte iyice netleşecek şekilde ayrışmaktadır. Çünkü aydınlanma çağı, insanın dünya üzerinde bir hakimiyeti olabileceği, insanın doğanın kanunlarının ötesine geçebileceği gibi görüşlerle insanı merkeze çekmiş, özel mülk iyiden iyiye düşünülmeye başlanmıştır. Bunlarla birlikte artık insanın doğası konusunda da farklı görüşler ortaya çıkmaktadır. Bu çalışma genel olarak kendinden önceki düşünürlerden farklılaşan Locke ve Rousseau'nun insan doğası ve toplum anlayışına odaklanmıştır. İnsan doğası düşüncelerinin temelini incelerken buraya referansla nasıl bir toplum ve yönetim kurmayı hedefledikleri de tartışma konuları arasındadır.

Locke ve Roussea'nun görüşleri birçok yazar tarafından ele alınmıştır. Fakat bu çalışmaların ortak noktası çoğunlukla Locke ve Rousseau'nun düşünce sistemleri içerisinde bir odak noktası oluşturmaları ve tartışmaları bu noktada derinleştirmeleridir. Birazdan görüleceği gibi bu çalışmalar kendi "kavram"larına odaklandıkları için insan doğası tartışmasını dışarıda bırakarak veya kısaca değinerek, Locke ve Rousseau'ya ait birçok kavramın ana eksenini de göz ardı etmişlerdir. Örneğin Ruby, Locke'un devletin oluşmasına dair görüşünü şöyle açıklar: "Devlet mutlu bir doğa halini en iyi şekliyle korumayı dileyen insanların kendi aralarında imzaladıkları bir ilk sözleşmeden dolaysız olarak doğan bir siyasi esere dönüşür" (2012, s. 81). Ruby'nin bu tartışması, devleti bir serbest birleşme olarak ele almaya kadar gider. Fakat böyle yaptığı için de Locke'un insanın aslında toplum içinde yaşamaya müsait bir varlık olarak yaratıldığı dolayısıyla bir toplumla uyum içinde olmayı aklı tarafından seçebileceği argümanını gözden kaçırır. Bir başka yerde de Strauss, Rousseau'yu ele alırken, bireyle toplum arasındaki çatışmayı nasıl çözümlediği yönündeki tartışmaya değinir, yine Rousseau'nun insan doğasına dair çıkarımlarına değinmeden ele aldığı için, bireyle toplum arasındaki çatışmayı çözümsüz bir durum olarak görüp, sadece Rousseau'nun bu çatışmayı nasıl anladığına odaklanmak (Strauss, 2011, s.292) zorunda kalmıştır. Tennenbaum ve Schultz’a göre, Locke'un insan doğası anlayışında insan doğası, potansiyel olarak bir kaç unsurun erdemli karışımıdır: Ahlak, rasyonel, bencilce ve toplumsal (Tannenbaum ve Schultz, 2008, s. 294). Fakat kavramın kısa bir betimlemesini veren yazarlar bu kavramın düşünürlerin fikirlerindeki yerine değinmezler.

Bu çalışma, Locke ve Rousseau'nun, insan, insan doğası ve toplum anlayışlarının genel olarak siyasal düşüncelerine, özeldeyse; sözleşme, hak, mülkiyet, yönetim v.b. kavrayışlarına etkisine odaklanmaktadır. Çalışmanın temel argümanı Locke ve Rousseau'nun insan doğası ve toplum anlayışı kavranmadan, onların kendilerine özgü sistemlerinin yanlış anlaşılacağı yönündedir. 


\title{
John Locke'un İnsan Doğası ve Toplum Anlayışı
}

John Locke düşünce tarihi açısından önemli bir dönüm noktasıdır. Locke’un farklılığı, insanın doğuştan idelerle dünyaya geldiği yönündeki düşünceye ve apriori bilgi kuramlarına bir saldırı biçiminde geliştirdiği kendine özgü tümevarımcı yönteminde yatar. Bu bağlamda Locke, özellikle Hobbes ve Gassendi'nin deneysel materyalizmine karşı yeni bir anlayış geliştirmektedir.

Avrupa'da kendinden sonra ortaya çıkan hemen hemen her düşüncenin etkilendiği Locke, insan ve insan doğasına dair görüşleri itibariyle de diğer düşünürlerden farklılaşmaktadır. Locke'un insan doğasına dair düşünceleri özellikle yakın arkadaş1, Ommerset Kontluğu'ndan parlamento üyesi olan Chipley'li Edward Clarke'a çocuklarının eğitimi için tavsiyelerde bulunmak üzere yazdığı mektupların bir araya getirilmesiyle oluşturulan Eğitim Üzerine Düşünceler (Locke, 2004) isimli kitabında ayrıntılı olarak ele alınmaktadır. Locke işe insanın bu dünyadaki görevini belirtmekle başlar. O, ülkesine hizmet etmenin her insanın kaçınılmaz görevi olduğuna ve bu düşünce olmaksızın insanla sığır arasında bir fark olmadığına inanır (2004, s. 10).

İnsana böyle bir misyon yükleyen Locke (2004), bu görevi ancak çocukların aldıkları eğitimle başarabileceklerini düşünür ve en büyük sorumluluğu anne babalara verir:

\begin{abstract}
"Çocukların iyi eğitimi ebeveynlerin öyle önemli bir görevi ki ve ulusun refahı ve gönenci buna o kadar bağımlı ki bunu herkesin içten bir şekilde benimsemesini ve hayal, gelenek ve mantığın bu konuyla ilgili tavsiyelerini iyice inceledikten, bunlar arasında gerekli ayrımı yaptıktan sonra gençliğin farklı şartlara göre eğitimi için herkesin her yerde yardım elini uzatmasını sağlamak istiyorum. Bu her meslek dalı için yapılması gerekli çok şey olsa da farklı meslek alanlarında erdemli, faydalı ve yetenekli insanların yeşertilmesini sağlayacak en kolay, en kısa ve en uygun yoldur: Bir rütbeye ait kişiler eğitimleri sayesinde doğruyu buldular mı diğerlerini de hizaya sokacaktır" (s. 11).
\end{abstract}

Böylece Locke, doğru yolu bulan "birileri”nin diğerlerini de hizaya -doğru yolasokacağını düşünür. Bu anlayış Platon'dan beri devam eden bir düşüncedir. Zira, birilerinin, diğerlerine nazaran-ister doğaya ister Tanrıya atılla yapılsın- üstün olduğu, yönetebileceği, eğitebileceği veya doğru yolu gösterebileceği bir çok kez gündeme getirilmiştir.

Birçok düşünür gibi Locke'a göre de insan toplumsal bir varlıktır. Fakat Locke’un bu vurgusu doğrudan bir Tanrı inancıyla bağlantılı görülmektedir: "İnsanı toplumsal bir varlık olmak üzere yaratan Tanrı, ona, yalnızca kendi türünden varlıklarla beraber yaşama eğilimi ve zorunluluğu sunmakla kalmayıp en güçlü toplumsal araç ve bağ olan dili de bağışlamıştır" (1999b, s. 11). Böylece Locke'un 
insanın konuşabilme olanağını Tanrıya atıfla açıkladığı görülmektedir. Birazdan görüleceği üzere Rousseau'da bu anlayış farklılık arz etmektedir.

Locke'un insan algısı, insanın, doğanın ona bahşettiği özelliklerle var olduğu fakat bunların eğitimle dönüştürülebileceği üzerinedir. Ona göre zihni akıllıca işlemeyen kişi hiçbir zaman doğru yolu seçemeyecektir; ve vücudu hasta ve zayıf olanlar ise hiçbir zaman ilerleme kaydedemeyecektir. Eğitim Üzerine'de (Locke, 2004) bu düşüncesini şöyle ifade eder:

"Bazı insanların zihin ve vücut yapıları o kadar dinçtir ve doğa bunları öyle güzel şekillendirmiştir ki bu insanların diğerlerinin yardımına çok ihtiyacı olmadığını itiraf etmeliyim; doğal dehalarının gücüyle beşiklerinden itibaren mükemmelliğe doğru ilerlerler; ve mutlu yapılarının ayrıcalığıyla harikalar yaratmaya muktedirdirler" (s. 13).

Yani Locke, bazılarının doğuştan mükemmel olduğu kanısındadır fakat Locke'a göre bunlara ait örnekler çok değildir. Böyleleriyle karşılaşıyorsak da "karşılaştığımız tüm insanlardan onda dokuzu eğitimleri sebebiyle bu haldedirler; iyi veya kötü, faydalı veya faydasız olurlar. Tatlı hayallerimizdeki küçük, hemen hemen fark edilmeyecek izlenimlerin çok önemli ve uzun süreli sonuçları vardır” (2004, s. 13). Türkiye'de yaşayanların da Cumhuriyet ideolojisi dolayımıyla aşina olduğu; sağlam vücutta sağlam kafa sözü Locke'un da tekrar ettiği bir sözdür ve ona göre mutluluk halinin kısa fakat tam tanımlamasıdır bu: "Bu ikisine sahip kimsenin isteyeceği çok az şey olur. Bunlardan birisinin eksikliğini çeken ise daha az iyi bir hayat sürecektir. İnsanın mutluluğu veya mutsuzluğunun en büyük sebebi kendisidir" (2004, s. 13). Dikkatle bakıldığında fark edileceği üzere Locke, insanın mutluluğunu kendisine indirger. Bu anlayış, aynı zamanda birey temelli düşüncenin ilk formudur. Bireyin kendi mutluluğunun sebebi olması, toplumdan ayrılan bir birey kurgusunu da beraberinde getirmektedir. Oysa aşağıdaki tartışmalarda da görüleceği üzere Rousseau, bu konuda Locke'dan ayrilmaktadir.

İnsan doğuştan belirli bir yapıya sahip olsa da eğitimin bu yapıyı değiştirebileceği fikrine sahiptir Locke. Eğitimin dokunduğu insan Locke'a göre nehirlere elle yapılan müdahaleler gibidir: "Bazı nehirlerin kaynaklarına elle yapılan nazik bir dokunuş suları kanallara yöneltir, bu kanallar da oldukça farklı yönlere akar ve onlara kaynakta yapılan bu ilk yönlendirme sayesinde farklı yönelimler alırlar ve sonunda çok uzak yerlere ulaşırlar" (2004, s. 13). Bir başka yerde de Locke, eğitimin etkisine şöyle dikkat çekmektedir; "insanların davranış ve yeteneklerinde bulunacak farklar her şeyden daha çok aldıkları eğitimlerin sonucudur” (2004, s. 32). Peki, insani varlık eğitimle bu kadar belirlenebilir bir varlıksa, o zaman "insanı diğer varlıklardan farklı kılan şey nedir” diye sorulduğunda yanıt ne olur? Locke, insanı öteki duyarlı 
varlıklar üzerine çıkaran ve onlar üzerindeki üstünlük ve egemenliğini sağlayan şeyin anlama (understanding) olduğuna dikkat çekmektedir (1999a, s. 57).

Eğitimle bu kadar farklılaşan bir insan varsayılmış ve anlama yeteneği daha gelişkin olarak düşünülmesine rağmen, Locke, nasıl ki insanın iki kolu ve iki bacağ vardır -Tanrı tarafından verilmiştir- ve bunu değiştiremeyiz, aynı şekilde insanın değiştirilemez karakter özelliklerinin de olduğuna değinir. Çocukların "kendilerine özgü halini tamamıyla değiştirmeyi, neşeli birini dalgın ve ciddi; melankolik olanı da canlı yapmayı umut etmemeliyiz. Tanrı vücut şekilleri gibi insanların zihinlerine belirli karakter özellikleri yerleştirmiştir" (Locke, 2004, s. 51). Locke’a göre bu durum çok az düzeltilebilir: "Bunları tamamılla değiştirmek ve aksine çevirmek mümkün olmayacak kadar zordur" (2004, s. 51). Fakat yine de eğitim bir terbiye aracı olarak görülmektedir. Locke, eğitimle insanın doğal yapısında bulunan kabalığın ortadan kalkacağını savunur. Böylece bir toplumda "önemli" yerler edinmiş insanların bu kabalıklarını ortadan kaldıran insanlar olduğunu ileri sürer: "...Görgü sahibi olmadığ düşünülen insanlar toplumda asla yer sahibi olamazlar. Çünkü terbiyenin amacı, doğal sertliği kırarak ve insanın huylarını yumuşatarak birbirlerine ve ilişkide bulunduğu insanlarla uyumlu hale getirmektir" (2004, s. 130).

Buradan hareketle, eğitimcinin veya çocuklarla beraber olan kişinin onların doğalarını ve yeteneklerini iyi gözlemesi ve sık denemelerle ne yöne kolayca döndüklerini görmesi; doğal birikimlerinin ne olduğunu ve bunun nasıl iyileştirilebileceğini ve onlar için neyin iyi olduğunu iyice anlamaları gerektiğini söyler (Locke, 2004, s. 51-52). Locke, doğuştan insanın verili bir doğaya sahip olduğuna dikkat çekiyor ve bu doğanın keşfedilmesi gerektiğine önem veriyor gibi görünmektedir. Buradan şu sonuca ulaşılabilir: İnsan eğitim aracıllğıyla değiştirilebilir fakat ilk iş insanın değişmeyen özünün keşfedilip onun derinlemesine geliştirilmesinin önünü açmak olmalıdır. Doğasında marangozluk yeteneği olmayan bir çocuğa marangozluk eğitimi vermek de yararsız bir uğraş olmaktan başka bir şey değildir. Bazıları doğuştan mükemmel bir zekâya ve bedene sahip olsa da bunlar çok azdır. Önemli olan insanların doğalarını keşfedip onları eğitimle istenilen düzeye getirmektir.

Locke, insanların ve toplumların ahlak yasaları üzerine de fikirler ileri sürmüştür. Locke’a göre insanın doğuştan getirdiği ahlaksal yasalar yoktur. Bir ahlak kuralının doğruluğu onların öncesindeki bazı etkenlere dayalıdır. Locke’a göre, bir ahlak yasasının anlaşılması için, içinde oluştuğu koşulları da düşünerek çıkarımlar yapmak gerekmektedir. İşte o zaman ancak ahlak yasalarının her toplumda farklılık gösterdiği görülecektir. Yani Locke’a göre bir toplumdan bir topluma geçtiğimizde aynı ahlak yasasının iki toplumda da var olduğunu görebiliriz. Bu durum, toplumların ortak ahlak yasalarına sahip olduğu anlamına gelmemelidir. Çünkü eğer böyle düşünülürse, ahlak yasaları "doğuştan" geliyormuş gibi görünebilir. Oysa Locke göre ahlak yasaları aynımış 
gibi görünse de bu görüntü üzerinden ahlak yasalarının birlikteliğinden bahsedilemez. Örneğin, insanların sözlerini tutma yükümlülügünün ahlaklılık kapsamında önemli ve yadsınamaz bir kural olduğunu varsayalım. Bu kural birçok toplumda ortak görünse de farklıdır. Çünkü Locke’a göre öbür dünyada mutluluk ve mutsuzluk kaygısı taşıyan bir Hıristiyan'a: 'Neden bir insan sözünü tutmalıdır' diye sorulduğunda 'Çünkü Tanrı böyle istiyor'; Hobbes gibi düşünen birine sorulduğunda 'yoksa devlet cezalandırır'; eski düşünürlerden birine sorulduğunda da 'başka türlü davranmak, insan doğasının kusursuzluğunun en üst noktası erdeme ters düşmek, onuru gölgelemek olur' biçiminde yanit alınır (1999a, s. 77).

Görüldüğü üzere Locke, ortak ahlaki ilkelerin olmadığını, aynıymış görünse de farklılık arz edebileceğini ileri sürmektedir. Bu çıkarsamayı yapan Locke'a göre ortak toplumsal bağın temeli adalet ve dürüstlük ilkelerinin kurulmasıyla atılır. Evet bu doğrudur fakat böyle bir zorunluluğu varsaymak bu ilkelere insanın doğuştan sahip olduğu anlamına gelmez:

"Adalet ve dürüstlük ortak toplumsal bağlardır; dolayısıyla kendileri dışındaki dünyadan kopuk yaşayan suçlular ve soyguncular arasında da aralarındaki birliğin bozulmaması adına adalet inancı ve kuralları korunmalıdır. Fakat kimse çıkıp da dolandırıcılık ya da yağma ile yaşamlarını sürdüren bu insanların kabul ettikleri ve onayladıkları adalet ve dürüstlük ilkelerine doğuştan sahip olduklarını söyleyebilir mi? Yaşantılarında ters düştükleri şeylere zihinlerinin sessiz onayıla evet dedikleri öne sürülebilir" (Locke, 1999a, s. 74-75).

Her yaşantının kendine uygun zihinsel çıkarımlar ürettiğini söyleyen Locke, "o zaman derim ki, insanların eylemleri kendi düşüncelerinin en iyi yorumlarıdır" (1999a, s. 75) demektedir. O zaman yaşamdan bağımsız bir toplulukta ahlaki ilkelerin olmadığını söyler. Fakat bu hiçbir şekilde bir ahlaksal yasanın kendiliğinden olmadığ1 veya insanın doğuştan serbest doğduğu anlamına gelmez. İşte Locke burada bir ayrıma giderek Tanrısal Yasa dediği şeyi devreye sokar. Tanrısal Yasa, Locke göre,"Tanrının, insanların eylemlerine, ister doğanın ışığı isterse Tanrısal bildirişin (esinlenmenin) sesiyle duyurulmuş olsun, koyduğu yasadır" (1999a, s. 472). Tanrısal yasayı böyle tanımlayan Locke (1999a) şöyle devam eder;

\footnotetext{
"Sanırım Tanrının insanların kendilerini yönetmede başvuracakları bir kural getirmiş olduğunu yadsıyacak denli ahmak biri yoktur. Tanrının bunu yapmaya hakkı vardır; biz onun yarattıklarıyız. O, eylemlerimizi en iyiye yöneltecek ustun iyilik ve bilgelik sahibidir. Ve öteki yaşamda sonsuz süre ve ağırlıkta ödül ve cezalarla koyduğu yasayı uygulama gücündedir.Çünkü kimse bizi onun ellerinden alamaz. [Ahlaksal doğruluğun biricik mihenk taşı da budur ve] insanlar eylemlerinin en önemli ahlaksal iyi ya da kötüsünü bu yasaya göre yargılarlar yani günahlar ya da ödevler olarak eylemlerinin Yüce Tanr1nın ellerinden gelecek mutluluk ya da mutsuzluğa ulaştırıp ulaştırmayacağını bu yasa temelinde değerlendirirler." (s. 472-473)
} 
Hem burada hem de "ün" ile ilgili belirttiği her ne kadar saygınlık erdemin gerçek temeli olmasa da (çünkü bu insanoğlunun görev bilgisiyle ve Tanrı'nın ona verdiği ışığın dikte ettiklerini takip ederken kabul görme ve ödüllendirilme umuduyla Yaradan'ına itaat etmenin verdiği tatmin duygusudur) ona en yakın olanlardan birisidir, (2004, s. 48) sözünde de değindiği üzere Locke kimi yerde idealist bir tarzda görüşünü dile getirmektedir.

Tanrının bahşettiği ilkeler belirleyici olsa da burada asıl dikkat edilmesi gereken Locke'un doğrudan Tanrı tarafından insanın içine yerleştirdiği ilkelere göre insanın davrandığı yönünde bir fikir sunmamış olmasıdır. Evet Tanrısal ilkeler vardır ama bunlar insanın içine yerleştirilmemiştir; doğuştan getirdiğimiz birtakım ilkeler değildir, ama uyduğumuz bazı ilkeler varsa bu insan olmamızdan kaynaklı geliştirdiğimiz ilkelerdir:

"İnsanların bilgisizliğini ayrımsayan, elinde en mağrur suçluyu bile dize getirecek gücü tutan Tanrı, erdem ile mutluluğu sıkı sıkıya bağlantılandırmış ve erdemli yaşantıyı toplumun birlikteliği adına gerekli ve tüm insanlık için yararlı kılmış olduğundan, kuşkusuz herkes kendisine mutluluk getireceğinden emin olduğu kuralları kabul etmekle kalmayıp başkalarına da övmeli ve önermelidir." (Locke, 1999a, s. 78)

Locke'un hem burada hem de birazdan alıntılandırılan pasajında vurguladığı bu "ahlaki ilkeler" insanın insan olmasından dolayı uyması gereken ilkeler olarak düşünülmektedir, ama doğalarının bir parçası değildir (2012):

"İnsanların biri diğerine söz verebilir, anlaşmalar yapabilir ve yine de doğa durumunda olabilir. İki insan arasında, Garcilasso De la Vega'nın, Peru Tarihi adlı eserinde sözünü ettiği ıssız adadaki ya da bir İsveçli ile bir Kızılderili arasında Amerika ormanlarındaki mübadele vb. pazarlıkları ve sözleri, bu kişiler tam anlamıyla bir doğa durumunda olmalarına rağmen birinin diğeriyle ilişkisi bakımından bunlar için bağlayıcıdır. Çünkü dürüstlük ve ahde vefa toplumların üyeleri olmalarından dolayı değil insan olmalarından dolayı insanların görevidir" (s. 16).

Tüm bu ahlaksal ilkeler karşısında insan bilinci, insanın kendisine kılavuzluk edecektir ama ahlak ilkeleriyle kendi davranışının uygunluğunun karşılaştırmasını yapması da beklenmektedir:

“İster istençli eylemlerimizin doğruluğunu sınama ve buna göre adlandırmada bir mihenk taşı gibi gördüğümüz kural, isterse ülkenin ahlak anlayışından edindiğimiz ya da bir yasamacının istencinden doğan kuraldan söz edelim, zihin herhangi bir eylemin o kuralla bağıntısını gözlemleyebilecek ve eylemin bu çerçevede uygun olup olmadığına karar verebilecek yetenektedir." (Locke, 1999a, s. 477-478) 
Locke, insanın bilincini, insanın kendine kllavuz olarak vermektedir. Diğer taraftan doğuştan bir takım özellikler getirilmiş olsa da eğitimle insanın değiştirilebilir olduğunu savunmaktadır. Fakat burada bir ayrım yapmak gerekmektedir. Locke insanın çok yönlü bir potansiyelinin olduğuna vurgu yapmaz. Eğitimle terbiye verilebileceğini ve onun aracılı̆̆ıyla törpülenebileceğini söyler. İnsan, yukarıda da anıldığı gibi Locke'a göre, toplumda bir uyum içerisinde yaşamak için yaratılmıştır. Ama bu, insanın içinde bulunduğu topluma, dini anlayışa veya devlete doğrudan bir boyun eğmesini gerektirmez. İnsanın ister toplumla ister devletle kurmuş olduğu ilişki bir köle ilişkisi değildir. İnsanın ilişkisi özgür ve erdemli bir insanın ilişkisi gibi olmalıdır. Zaten Locke'un insanın doğuştan bir ahlak ve Tanrı inancı getirmediği yönündeki vurgusu buraya referansla anlaşılabilir. Şimdi bu kısa hatırlatmadan hareketle, Locke'un insan doğası ve toplum anlayışının onun siyasal sistemindeki devlet anlayışına nasıl etki ettiğine, aynı zamanda Locke'un devleti kendi düşüncesinde nasıl konumlandırdığına genel hatlarıyla bakmakta fayda var.

Locke, insanın doğa durumunda nasıl bir pratik sergilediğine değinir. Fakat Locke'un insanın doğa durumunda özgür mü yoksa hürriyetinden yoksun mu olduğu konusunda tutarlı ve sistematik bir görüş ileri sürmediği söylenebilir. Farago'ya göre Locke doğal durumda insanları özgür olarak düşünür. "Bu özgürlüğün anarşi olmadığı ve insanlar arasındaki eşitliğin savaş durumuna yol açmadığı bir durumdur" (Farago, 2013, s. 297). Fakat yukarıda da değinildiği gibi bu görüş kesin değildir. Örneğin Locke (1980; 2012), şuradaki tartışmasında insanın doğa durumunda özgür bir halde olduğu fikrine karşı çıkar:

“Eğer insan doğa durumunda söylenmiş olduğu kadar özgürse, kendi kendisinin ve mal varlığının mutlak efendisiyse, en büyüğe eşit ve hiç kimseye tabii değilse, özgürlüğünü neden terk edecektir? Bu imparatorluğu neden bırakacak ve kendisini başka bir İktidarın hükümranlık ve denetimine tabii kılacaktır?" (s. 66; s. 81). ${ }^{1}$

Locke (2012) kendi sorduğu sorulara cevabın açık bir şekilde şöyle verilebileceğini söyler:

"Doğa durumunda insan bu tür bir hakka sahip olmasına rağmen, bu hakkın kullanı$\mathrm{m}$ oldukça belirsiz ve sürekli olarak başkalarının tecavüzüne maruzdur. Herkes diğeri kadar kral, her insan diğerinin eşiti olduğundan ve hakkaniyet ve adaletin kuvvetli gözetleyicileri olmayanlar daha büyük bölümü oluşturduklarından, insanın bu durumda sahip olduğu mülkiyetin kullanımı oldukça güvenliksiz, oldukça emniyetsizdir” (s. 81). 
Yukarıda görüldüğü üzere de Locke’a göre insan aslında doğa durumunda özgürdür. Belki bu karmaşa Locke'un ne kastettiği ele alınarak giderilebilir. Kısaca söylemek gerekirse şu söylenebilir: İnsan doğa durumunda özgür olmasına rağmen özgür değildir. İnsan özgürdür, özgürlük hakkı vardır fakat sürekli tehdit altında olduğu için bu özgürlük hiç bir işe yaramamaktadır. İşte Locke’a göre insan sürekli tehdit altında olmasından dolayı bu özgürlüğü kullanamadığı için bir toplulukla yaşamak ve bir devlete ihtiyaç duymak ister. Locke'un insanların bir arada yaşamasının doğa veya Tanrı tarafından verildiği anlayışı da burayı meşru gösterme veya insanın bir arada yaşama isteğini anlamlandırma çabası olarak anlaşılmalıdır. Çünkü insanın doğuştan bir bilgiyle gelmediğini, insanın doğuştan ahlaksal ilkelere sahip olmadığını söyleyen Locke (1980; 2012), konu insanın topluluk içinde yaşamasına gelince aynı tavrı takınmaz. İnsanın bir arada yaşama isteğini doğrudan Tanri'ya bağlar:

\footnotetext{
“Tanrı insanı, yalnız kalmanın, kendi düşüncesiyle iyi bir şey olmadığını anlayacak bir yaratık olarak yaptı; insanı topluma yönlendirdi. İnsanı çok güçlü rahatlık, gereksinim ve eğilim yoluyla topluma yönlendirdi; aynı şekilde toplumu sürdürmesi ve toplum içinde yaşaması için insana anlama yetisi ve dil yerleştirdi” (s. 42; s. 53).
}

$\mathrm{Bu}$ durumun bir diğer yorumu ise Strauss tarafından şöyle dile getirilmektedir: Locke’a göre "Doğa insana hayatını ve varlığını korumak için güçlü bir arzu yerleştirmiştir, neyin 'varllğı için gerekli ve faydalı' olduğunu insana öğreten ise sadece onun usudur" (Strauss, 2011, s. 262-263). Arnhat ise usun, Locke'un düşüncesindeki insan haklarının temelini de oluşturduğunu söyler: “İnsan haklarının temeli, insan aklı sayesinde her insanın aşağı mertebedeki yaratıklar’ için imkânsız olan, kendisinin efendisi olma melekesidir" (2005, s. 233). Peki, eğer insanın içinde böyle bir eğilim varsa yani akıl zaten bir arada yaşamayı insana mümkün kılıyorsa, belirli bir mülkiyet korkusu yaşamasına gerek kalmadan insan doğrudan topluluk içinde yaşamaya başlayamaz mıydı? Diğer taraftan böyle bir kavrayış insanın dünyada var olduğundan beridir niçin aynı biçimdeki devletler ve toplumlar kurmaya başlamadığını ve neden hemen her çağda niteliği, biçimi farklı onlarca toplum ve devletin karşımıza çıktığını yanıtlamakta cevapsız kalmaktadır.

İnsanlar doğa durumunda güvencesizdir. "Tek çare, hükümet veya sivil toplumdur. Buna göre us sivil toplumun nasıl kurulması gerektiğini ve onun haklarının ve sınırlarının neler olacağını dikte eder" (Strauss, 2011, s. 264) olduğu için bir yasayla aralarında barışı tesis etmeleri gerekmektedir. Çünkü Locke’a göre, doğa durumunda, insanın sahip olduğu mülkiyetin kullanımı güvencesizdir, "dolayısıyla insanların devletlerde birleşmelerinin ve kendilerini yönetim altına koymalarının asıl ve ana amacı, mülkiyetlerinin korunmasıdır. Doğa durumunda ise bu konuda pek 
çok şey eksiktir" (2012, s. 81; 1980, s. 67). Locke'un bu şekilde ortaya koyduğu fikrine karşı Farago'ya göre Locke, Hobbes'un aksine doğal durumda akılla düzenlenmiş göreli bir barış durumu bulmaktadır (2013, s. 297).

Insanın böyle bir güvenliksiz ve güvencesiz ortamda olması, Locke’a (2012) göre insanı "özgür olmakla birlikte korku ve sürekli tehlikelerle dolu olan bu durumu terk etmeyi istemeye zorlar ve dolayısıyla insanın, benim genel olarak Mülkiyet adıyla adlandırdığım, yaşamlarının, hürriyetlerinin ve servetlerinin karşılıklı korunması için önceden birleşmiş bulunan ya da birleşme fikrine sahip olan diğer insanlarla birlikte bir topluma katılmayı amaçlaması ve bunu istiyor olması nedensiz değildir." (s. 81)

Kısaca, Locke'un düşüncesinde insanın bir topluluk içinde bulunması iki gerekçeye dayandırılmaktadır; birincisi zaten Tanrı'nın, insanı yalnız kalmanın kötü olduğunu sezecek bir varlık olarak yaratmasıdır; ikincisi, insanın ancak bir topluluk içinde haklarını tam olarak kullanabileceğini görmüş olmasıdır. Fakat burada da devletin rolünün ne olacağı sorunu ortaya çıkmaktadır. Hobbes, insanın özgürlüğünü, toplumdaki karmaşa ve anarşi riskinden dolayı feda edip bir otorite inşa etmenin derdindeyken, Locke, insanın özgürlüğünün kısıtlanmad1ğ1 aynı zamanda da keyfiliğe ve despotizme kaymayacak bir dizginlenmiş otorite hayali kurmaktadır. Bundan dolayı otorite "doğal yasa" ve halkın rızasıyla sınırlanmaktadır. Burada önemle üzerinde durulması gereken durum doğa yasasıdır. Doğa yasası bütün insanlara ebedi ve eksiksiz görevler yükler bundan dolayı da bir yasa görevi görür.

$\mathrm{Bu}$ yasa tesis edildiğinde ortaya çıkan toplum, bireyin haklarını güvence altına alır. Bu toplumun, kendi üyelerini baskı altında tutamayacak şekilde kurulması, bireyin haklarını güvence altına alması için gereklidir. Yukarıda değinildiği gibi bu durum Hobbes'un kavrayışından farklıdır. Çünkü Hobbes, tam aksine üyelerine sirayet edebilen bir toplum ve buna bağlı olarak da bir egemenlik inşa etmektedir. Oysa Locke'un düşüncesinde toplum veya sivil toplum bireyin kendi haklarını yaşayabilmesi için garantör niteliktedir. Strauss'un dikkat çektiği gibi, "Yine de sivil toplum, sivil mülkün yaratıcısıyken onun efendisi değildir: sivil toplum sivil mülkiyete saygı duymalıdır; sivil toplumun, adeta kendi yarattığına hizmet etmekten öte bir işlevi yoktur" (2011, s. 270). O zaman toplumun insan doğası uygun bir birliktelik olduğunun altını çizip, Locke’a göre toplumun insan için iki önemli görevi sağladığı söylenebilir: "Toplum doğal olarak bir yandan insanın yaşamının ve vicdanının özgürlüğünü eline geçirmesine, öte yandan ve daha çok, emeğe sunulmuş doğanın maliki olma isteğine dayanır” (Kriegel, 2010, s. 102). 


\section{Jean-Jacques Rousseau'un İnsan Doğası ve Toplum Anlayışı}

Aydınlanma çağının düşünürü olmasına rağmen aydınlanmanın yol açtığı yıkımlara, uygarlık nosyonuna ve akla dair savunulara bir tepki niteliğinde fikirler ileri süren Rousseau, en önemli kitaplarından biri olarak görülen Toplum Sözleşmesi’ne Vergilius'un “foederis aequas Dicamus leges" sözüyle² (Vergilius, 1998) ve daha sonra kendi sorusu olan "yurttaşlık düzeninde insanları oldukları, yasaları da olabilecekleri gibi kabul ettiğimizde meşru ve güvenli bir yönetim olabilir mi?” (Rousseau, 1999, s. 27) ile başlar. Rousseau'nun temelde yanıt aradığı soru buradan hareketle, eşitliği ve özgürlüğü temel alan iyi bir yönetimin mümkün olup olmadığıdır. Rousseau için özgürlük ve insanın özgür olarak karar vermesi temel bir meseledir. İnsanın özgürlüğünü kısıtlayan koşulları meşru gösteren her şey de Rousseau'nun doğal olarak eleştiriye tabi tuttuğu durumları oluşturmaktadır. "İnsan özgür doğar, oysa her yanda zincire vurulmuş durumda. Kendilerini başkalarının efendisi sananlar bile onlardan daha az köle değil. Özgürlükten köleliğe doğru bu değişiklik nasıl olmuş, bilmiyorum. Bu değişimi kim meşru kılabilir?” (Rousseau, 1999, s. 29) derken dikkat çektiği nokta budur. Bu bağlamda Rousseau'nun insan doğası kavramsallaştırması hem insan doğasına uygun olarak olması gerekeni hem de insan doğası eğer uygarlık tarafından bozulmamış olsaydı olabilecek ya da olması gerekeni kapsar (Goyard-Fabre, 2013, s. 48). Bundan dolayı da Rousseau, uygarlığa savaş açmış ve sosyal sistemin çelişkilerini kurumların adaletsizliklerini ve aşırılıklarını uygar insanın yozlaşmışlıklarını ifşa eder (Goyard-Fabre, 2013, s. 49).

Rousseau, hemen hemen her kitabinda, doğa durumuyla uygar toplum olarak adlandırdığı kendi dönemini karşılaştırır. Onun için öncelikle Rousseau'nun doğa durumu dediği şey ve "insanın doğasının iyi mi yoksa kötü mü” olduğu yönündeki soruya ne yanıt verdiğiyle başlamak isabetli olacaktır. Rousseau'nun doğa durumu anlayışı Locke'un düşüncesindeki gibi belirsiz bir zaman veya hayali bir kurgu değildir. Rousseau, hemen hemen her yerde doğa durumundan bahsederken, insanın ilk yaban halinden bahsettiği, uygarlık öncesi dönemi andığı çok belirgin bir şekilde görülmektedir. Ayrıca Rousseau'nun doğa durumu tasviri Hobbes ve Locke gibi düşünürlerin doğa durumu anlayışını eleştiri üzerine kuruludur. Çünkü ona göre bu düşünürler hoşa giden bir sonuç ortaya atmakta, ardından bunun rasyonelliğini ve tarihselliğini kanıtlamak amacıyla kendi kafalarına göre ilkeler, kurallar oluşturmakta ve böylece doğa durumuna tarihsellik atfetmektedirler (Ağaoğulları, 2006, s. 35-36).

2 foederis aequas Dicamus leges: İnsanlar arasında eşitliği sağlayan anlaşmalar yaptıktan sonra yasalar koyalım. Vergilius, Aeneis, XI. Kitap, (İstanbul: Öteki Yayınları, 1998). (Vergilius, 1998). 
$\mathrm{Bu}$ hatırlatmayla birlikte şunu da hatırda tutmakta fayda var; insanın doğası gereği iyi veya kötü olmasıyla doğa durumunun insan için elverişli olması ayrı şeylerdir. Rousseau'ya dair yanlış yargılar bulunmaktadır; Rousseau'nun insanı doğası gereği veya insanın doğal durumda iyi olduğunu varsaydığına dair fikirler söz konusudur. Ama Rousseau'ya göre, doğal durumda bu sorunun yanıtı yoktur: Hatta böyle bir şey mümkün de değildir. Çünkü "bu durumda olan insanların aralarında hiçbir ahlaki ilişki ya da kabul edilmiş görevler olmadığı için iyi ya da kötü olamazlardı" (1995, s. 118). Bir başka yerde ise insanlar arasındaki kötülüğün doğadan değil kendilerinden geldiğini söylemektedir (Rousseau, 1995):

"Bu yüce, derin düşüncelerimle coşan ve yücelen ruhum, Tanrı'nın huzuruna yükseldi. Oradan hemcinslerimin, peşin yargılarının, batıl inançlarının, yanılgılarının, mutsuzluklarının, suçlarının çıkmaz yolunda yürümeye çalıştıklarını görünce, işitemedikleri, zayıf bir sesle haykırdım: 'Durmadan doğadan yakınan çılgınlar, biliniz ki size bütün kötülükler kendinizden geliyor."' (s. 37-38)

Peki, Rousseau için doğa durumu veya doğa hali niçin önemlidir veya doğa durumunu elverişli kılan şey nedir? Doğa durumu mefhumuna ayrıntısıyla değinir çünkü Rousseau, doğa durumunun bireyin mutlak bağımsızlığını güvence altına aldığını düşünür (Strauss, 2011, s. 316). Doğa durumu Rousseau'ya göre elverişlidir ve iyidir çünkü "doğa hali, bizim kendi varlığımızı korumak için gösterdiğimiz özenin başkalarına en az zarar verdiği durum olduğu için, barışa ve insan türüne en elverişli olan durumdur" (1995, s. 119). Onun için Rousseau, insanın doğal durumda taşıdığı belirleyici şeyin akıl değil duyumlar olduğunu ileri sürmekte ve bu duyumların başında da merhametin geldiğini söylemektedir. Rousseau'nun bu düşüncesinin temeli, dönemin fikirlerine önemli etkilerde bulunmuş olan Condellac'tır. Condellac, analizler yoluyla ruhun karmaşık ilerleyişinin, en basit işleyişe indirgenebileceğini düşünür. Bu yöntemle şu sonuca ulaşılır: Her şeyin temelinde, duyum vardır; insan, düşünen bir varlık haline gelmeden önce duyar bir varlıktır. Rousseau'nun çıkarımları da bu fikirle benzerlik göstermektedir. Ona göre merhamet, "doğal bir duygudur; her bireyin kendisine karşı duyduğu sevginin faaliyetini hafifletip yumuşatarak, bütün türün, karşılıklı olarak kendini muhafazasına yardım eder" (1995, s. 124). Hatırlanacağı üzere Locke insanın akli bir varlık olduğunu söylüyordu ve Locke'un insan doğası ve toplum anlayışı da bu rasyonellik sayesinde anlaşılması gerektiğine değinilmişti. Fakat Rousseau, Locke'tan farklı düşünür. Elbette Rousseau'ya göre de insan akli bir varlıktır. Fakat bu akli olma durumu insanın birincil özelliği değildir. İnsanın akli bir varlık olmaktan önce duyar bir varlık olduğunu düşünen Rousseau, "doğa durumunda insanların birbiriyle ilişkisinin niçin bir kölelik ilişkisi doğurmadığına" dair soruyu şöyle yanıtlamaktadır: "Kölelik bağları insanların karşılıklı bağımlılıklarından, karşılıklı gereksinme- 
ler onları birleştirmeden önce meydana gelmediği için bir insanı, daha önce başka bir insandan vazgeçemeyecek bir duruma getirmedikçe kul edip köleleştirmek olanaksızdır." Rousseau'ya göre bu durum "doğa halinde hiç olmadığı için herkesi boyunduruktan azade bırakır, en güçlünün hükmetmesi kanununu boşa çıkarır" (1995, s. 130-131). Diğer taraftan Rousseau insanların doğuştan belirli "insani görünüm”lerle doğmadığını dile getirir. Rousseau'ya göre, insanlar doğuştan "ne kral ne büyük ne nedim ne de zengindirler. Her insan çılak ve yoksul doğar, her insan yaşamın sefaletleri, üzüntüleri, kötülükleri, ihtiyaçları, çeşitli acıları altında ezilir; nihayet hepimiz ölüme mahkumuz" (2009a, s. 408-409).

Rousseau'ya göre doğa durumunda insanlar hayvani bir niteliğe sahip değildirler. İnsanı, hayvanlardan ayıran birçok farklılık vardır. Rousseau (1995) şöyle der:

\begin{abstract}
"Bütün hayvanlarda, gerekli şeyleri yeniden elde etmek, kendisini yok etmek veya tedirgin etmek eğilimindeki her şeye karşı bir noktaya kadar kendini güven altına almak için doğanın yön verdiği, ustalıkla yapılmış bir 'makine' görüyorum, insan makinesinde ${ }^{3} \mathrm{de}$ tam aynı şeyleri görüyorum; şu farkla ki, hayvanın bütün işlerinde her şeyi sadece doğa yaptığı halde, insan kendi işlerinin yapılmasına, özgür bir unsur sıfatıyla kişi olarak katılır." (s. 102)
\end{abstract}

Rousseau'ya göre hayvan içgüdüsüyle, insan özgür eylemiyle seçer ya da reddeder; bunun sonucu hayvan, kendisine hükmeden kuraldan uzaklaşması kendisi için daha yararlı olduğu zaman bile, sapamaz; insan ise, kendi zararına olsa bile, çoğu kez uzaklaşabilir. Böylece bir güvercin, en iyi etlerle dolu bir leğenin başında, bir kedi de meyve ya da tahıl tanesi yığınının başında açlıktan ölür; oysa her biri küçümsediği yiyeceklerden beslenmeyi deneselerdi çok iyi beslenmiş olurlardı" (1995, s. 102). Görüldüğü üzere Rousseau, insanın doğada kendisine hakim olan durumdan iradesiyle ayrılabileceğini düşünür. Çünkü hayvan doğada kendi kısıtlılığı ile davranmak zorundadır. İnsanı hayvandan ayıran en önemli özellik ise, insanın kendi kendinin bilincinde olmasıdır -bu düşünce Feuerbach'ın yol göstericiliğiyle Marx'ın düşüncesinde, insanın bir tür varlığı olduğu yönündeki tartışmasına kadar gelişim gösteren bir hattır-. Rousseau'ya göre insan, dünyada hayvandan farklıdır çünkü, "doğa bütün hayvanlara emreder ve hayvan buna uyar. İnsan da aynı etkiyi duyar; fakat o, buna boyun eğmekte ya da direnmekte kendini özgür bilir. Onun ruhunun tinselliği bu özgürlüğün bilincine ulaşmasında kendini gösterir" (1995, s. 103). Rousseau'nun burada dikkat çektiği nokta daha önce dile getirilmemiş bir ayrımdır. Hayvanın doğanın emirlerine uyması ne demektir? Bu şöyle örneklendiri-

3 Rousseau'nun burada üzerinde durduğu fikre Descartes kaynaklık etmektedir. Descartes ve Bacon gibi etkin bilim insanları doğanın değişmez yasalarının olabileceği üzerinde fikirler ileri sürmüşlerdir. 
lebilir; bir arı düşünülecek olursa, bir arı bal yapmayı bırakırsa ne yapabilir? Hiç bir şey! Oysa insan doğanın kendisine karşı emrini kendi iradesiyle dönüştürme yeteneğine sahiptir. İşte Rousseau'nun ileri sürmüş olduğu ayrım buraya oturmaktadır.

Rousseau'nun insan ile hayvan arasında dikkat çektiği bir diğer ayrım ise dil üzerinedir: "Söz insanı öbür hayvanlardan ayırır: Dil ulusları birbirlerinden ayırır; bir insanın nereli olduğu konuştuktan sonra anlaşılır” (2007, s. 1). Dilin belirleyiciliği ile insan ve hayvan arasındaki farka başka bir yerde de şöyle değinmektedir (2007):

\begin{abstract}
"Hayvanların organ yapısı bu iletişim için yeterli olandan da fazladır, ama hiçbiri bunu kullanmamıştır. İşte bu bana son derece belirleyici bir fark gibi görünüyor. Bunların içinde toplu halde çalışanlar ve yaşayanların, kunduzların, karıncaların, arıların aralarında anlaşmak için doğal bir tür dilleri var, bundan hiç kuşkum yok. Hatta kunduzların ve karıncaların dillerinin jestlerden oluştuğuna ve sadece göze seslendiğine inanmamız da yersiz olmaz. Ne olursa olsun, bundan dolayı bu dillerin her biri doğal olsa da, edinilmiş değildirler; bu dilleri konuşan hayvanlar onlara doğuştan sahiptirler; hepsi bunlara sahiptirler, ve her yerde aynı dile sahiptirler; onu hiç değiştirmezler, en küçük bir ilerleme de göstermezler. Uzlaşımın dili sadece insana aittir. İşte bu nedenle insan, iyi yönde olsun kötü yönde olsun, ilerleme gösterir ve bu nedenle hayvanlarda ilerleme hiç görülmez" (s. 6-7).
\end{abstract}

Görüldüğü üzere Rousseau, Locke’un anlayışıyla farklılaşmaktadır. Locke’a göre insan dil yetisini Tanrı aracılığıyla edinmişti. Oysa Rousseau'ya göre dil insanın doğada gereksinimlerinden edinmiş olduğu bir yetidir. Rousseau'nun, insanın duyumsar özelliğinin belirleyiciliği ile dil üzerindeki görüşlerini biraz daha açmak gerekiyor fakat burada insan ve özbilinç ilişkisini daha iyi kavramak için bir ara verip Hegel'in düşüncesine uğramakta fayda var. Hegel'e göre kişinin kendi özbilincine varması karşılıklı tanınmayla gerçekleşir bu da bir mücadele içinde geçen sürecin sonucunda oluşur. "Özbilinç doyumuna salt başka bir özbilinçte ulaşır" (1986, s. 123). Bu varsayıma göre insan bir insan olarak var olmak için ötekine başvurmaya zorunludur. Ve hatta "bir özbilinç bir özbilinç için vardır." (1986, s. 124). Yani Hegel diyor ki bir öteki olmadan "ben" asla olamam, yani insan "ancak tanınan bir şey olarak vardır" (1986, s. 124). Buradan hareketle Hegel şöyle bir çıkarıma ulaşır: "İki özbilincin ilişkisi öyleyse kendi kendilerini ve birbirlerini bir ölüm kalım kavgası yoluyla tanıtlamaları olarak belirlenir” (1986, s. 127). Bu durumda bu mücadeleye girebilen varlıklar Hegel için "salt arı kendi-için-varlıktır. Yaşamını hiç tehlikeye sokmamış birey hiç kuşkusuz kişi olarak tanınabilir; ama bağımsız bir özbilinç olarak tanınmışlığın gerçekliğine erişmiş değildir” (1986, s. 127). Kısaca görüldüğü üzere Hegel için kişinin insanlaşması ve kendinin farkına -özbilince- ulaşması mücadele sonucu elde edilen bir şeydir. Rousseau (2007) için bu süreç mücadeleyle değil bir başkası tarafından hissedilmeyle veya düşünülmeyle gerçekleşir: 
"Bir insan başka biri tarafından hisseden, düşünen ve kendine benzeyen bir varlık olarak tanındığı anda ona kendi hislerini ve düşüncelerini iletme arzusu ya da gereksinimi, bunun araçlarını aramaya yöneltir. Bu araçlar, bir insanın başka bir insan üzerinde etkide bulunabilmesinin tek aletleri olan duyulardan çıkabilir sadece. İşte size düşünceyi anlatmak için kullanılan duyulur işaretlerin kuruluşu. Dili bulanlar bu akıl yürütmeyi yapmamışlardı ama içgüdü onlara bu sonucu esinledi” (s. 1).

Rousseau, böyle düşünür, çünkü yukarıda da değinildiği gibi ona göre insan düşünmeye başlamadan önce hisseder. Bu çıkarım Rousseau'ya (2007) daha temel bir çıkarım yapma imkânı verir ve insanların, gereksinimlerini ifade etmek için konuşmayı bulduklarını ileri süren düşünceyi eleştirebilme olanağı sağlar:

"Bu düşüncenin savunulabilir bir tarafını görmüyorum. Temel gereksinimlerin doğal etkisi insanları birbirlerinden ayırmak olmuştur, onları birbirlerine yaklaştırmak değil. İnsan türünün yayılması ve yeryüzünün çok hızlı bir biçimde insanlarla dolması için bu gerekliydi de; yoksa insan türü dünyanın bir köşesinde sıkışıp kalırdı ve geri kalan bölgeler issızlaşırdı" (s. 9-10).

Dikkat edilirse Rousseau'nun burada özgün bir düşünce ortaya koyduğu görülmektedir. Bu düşünce ise insanların temel gereksinimlerinden dolayı toplumsallaştığ1 fikrinin reddidir. Zaten Rousseau'ya göre insanlar ilk dönemlerini yaşarken temel gereksinimleri için bir araya gelmezler: "Bundan dolayı apaçık görünmektedir ki dillerin kökeni asla insanın temel gereksinimlerinden kaynaklanamaz; onları birbirlerinden ayıran nedenden onları bir araya getiren aracın doğması saçma olurdu" (2007, s. 9). Peki nerededir bu köken? Rousseau'ya göre bu, ahlaki gereksinimlerde ve güçlü duygulanımlardadır. Çünkü yaşamını sürdürme zorunluluğu, insanları birbirinden uzaklaşmaya zorlarken bütün güçlü duygulanımlar onları birbirlerine yaklaştırmaktadır. Bundan dolayı da Rousseau'ya göre, insanlardan ilk sesleri çekip alan açlık ya da susuzluk değil aşk, nefret, acıma, öfkedir. Meyveler elimizden kaçmazlar, konuşmadan da onları besin olarak kullanabiliriz; yiyeceğimiz avı sessizce izleriz; ama genç bir kalbi heyecanlandırmak için, haksız bir saldırganı püskürtmek için doğa vurguları, çığlıkları, yakınmaları dayatır: İşte en eski sözcükler böyle bulunmuştur ve bu nedenle ilk diller basit ve yöntemli olmaktan önce şarkıyla söylenen ve güçlü duygulanımlarla dolu dillerdir (2007, s. 9-10).

Böylece Rousseau, bir kez daha insanın dil gelişimini insandan hareketle ortaya koyarak Locke'dan farklı bir bakış açısı ileri sürer. Peki, insanın doğal hali nasıldı? Ve doğal hal kurgusu Locke'un düşüncesiyle farklılıklar barındırıyor mu? Şimdi bu soruların yanıtını aramaya çalışalım. Rousseau (2007) ilk zamanlarda insanların birbirlerine karşı düşmanlık beslediği varsayımını ileri sürer: 
“ìlk zamanlarda, yeryüzüne dağılmış durumdaki insanların sahip olduğu tek toplum aile, tek yasa doğa yasası, tek dil de jest ve kimi eklemlenmemiş sesler idi. Hiçbir ortak kardeşlik fikriyle birbirlerine bağlı değillerdi ve güç dışında bir hakem bulunmadığından birbirlerini düşman görürlerdi. Onlara bu kanııı veren güçsüzlükleri ve cehaletleriydi. Hiçbir şey tanımadıklarından, her şeyden korkarlar, kendilerini savunmak için saldırırlardı. Yeryüzünde insan türünün merhametine terk edilmiş bir adam yırtıcı bir hayvan olmak zorundaydı. Başkalarından gelmesinden korktuğu her şeyi onlara yapmaya hazırdı. Korku ve güçsüzlük acımasızlığın kaynaklarıdır." (s. 35)

Ama doğal durumda insanlar bir savaş halinde değildirler. Doğa durumunda insanlar salt kendilerini düşünen varlıklar olarak düşünülürler. Hatta bu yönüyle Rousseau, Hobbes'u da anımsatmaktadır. "Ancak insanın bu bencil yap1sı, Hobbes'tan farklı olarak, Rousseau'da insanların birbirleriyle savaştığı bir durumun doğmasına neden olmaz" (Ağaoğulları, 2006, 40). Rousseau'ya göre düşmanlık beslemeyle savaş halinde olma durumunun iki farklı şey olduğunu göz önünde bulundurmak gerekiyor. Zira doğal durumda insanların düşmanlık beslediğini söyleyen Rousseau, savaş halinde olmadıklarını da iddia etmektedir. Rousseau bu iddiasını ilksel bağımsızlıkları içinde yaşayan insanları örnek göstererek savunur. Bu insanların aralarında savaş ya da barış durumu yaratmaya yetecek denli sabit (constant) bir ilişki içinde olmadıklarından, doğal olarak, birbirlerine düşman da değillerdi. Rousseau'ya göre savaşa insan ilişkisi değil, eşya ilişkisi neden olur ve savaş durumu, basit kişisel ilişkilerden değil, yalnızca mal ilişkilerinden doğduğu için de özel ya da adam adama savaş, sürekli bir iyeliğin var olmadiğı doğal yaşam durumunda da her şeyin yasaların güvencesi altında bulunduğu toplumsal durumda da yoktur ${ }^{4}$ (1999, s. 39). Görüldüğü üzere, Rousseau doğa durumunda insanların birbirleriyle doğrudan savaş ilişkisi değil ama bir düşmanlık halinde bulunduklarını söyler. Locke bunu hatırlanacağı gibi insanların "mülkiyetlerinin" tehdit altında olması olarak nitelendirmekteydi. Locke ile Rousseau'nun toplum anlayışları birazdan karşılaştırılacak fakat öncesinde Rousseau'nun bir toplumun var olma nedenini nasıl açıkladığına biraz daha değinmek gerekiyor. İnsanları bir araya getiren ilk neden Rousseau'ya göre karşılıklı gereksinimdir. "Karşılıklı gereksinim insanları duygudan daha iyi bir biçimde bir araya getirirken, toplum ancak insan becerisiyle oluştu; sürekli yok olma tehlikesi jest diliyle sınırlanmaya izin vermiyordu, onlarında ilk sözü beni sevin değil bana yardım edindi" (2007, s. 52). Rousseau, insanın bir araya gelmesinin nedenini birkaç kez farklı şekilde ele alıyor. Şimdi göreceğimiz gibi insanların top- 
lumsal bir yapı haline gelmesini zaaflara ve eksikliklere de bağlamaktadır. Bundan dolayı insanı toplumsal yapan şeyin insanın zaafı olduğunu düşünür. Rousseau'ya göre yüreklerimizi insanlığa götüren ortak sefaletlerimizdir, insan olmasaydık insanlığa hiçbir borcumuz olmazdı. Her bağlılık bir yetersizlik işaretidir. "Başkalarına kesinlikle ihtiyacı olmayan biri kesinlikle başkalarıyla birlikte olmayı düşünmezdi. Sonuçta kırılgan mutluluğumuzu yaratan da bu zaafımızdır. Gerçekten mutlu insan yalnızdır... dolayısıyla bizim insanlara olan bağlılığımızın nedeni onların mutlu oldukları duygusundan çok mutsuz oldukları duygusundan kaynaklanır" (2009a, s. 407-408).

Buradan iki sonuç ortaya çıkıyor: Bir, insanlar kendi kendilerine yetmediği için, karşılıklı gereksinimlerinden dolayı bir arada yaşamak zorundadırlar. İki, doğa durumunda insanlar bir savaş hali değil ama düşmanlık içindedirler. Locke'a göre de doğa durumunda insanlar sürekli tehdit altındadır. Bundan dolayı Locke insanın servetinin, yaşamının ve hürriyetinin korunması için bir topluma katılmayı isteyeceğini düşünmektedir. Yani aslında Locke, insanın kendine yeter bir varlık olduğunu düşünüyor ama insan sürekli tehdit altında bulunduğu için de bir sözleşmeyle barış halinin tesisini zorunlu görüyor. Oysa Rousseau, zaten birbirine yetemeyen insanların bir araya gelmesiyle toplumun oluştuğuna değiniyor. Rousseau için insanı toplumsal yapan şey zaafı iken, Locke'a göre Tanrı, insanı yalnız kalmanın, kendi düşüncesiyle iyi bir şey olmadığını anlayacak bir yaratık olarak yarattığı için insan topluluk içinde yaşamayı seçmiştir.

Diğer taraftan Rousseau, mülkiyet konusunu da tartışmaya açarak insanlar arasındaki genel kavganın nedenine dair fikirler ileri sürer. Ona göre, mülkiyetin ortaya çıkması ile hemen, birçok kavga ve çatışma doğmuştur (1995, s. 140). Rousseau'ya göre uygarlık özel mülkün icadıyla başlar: "Bir toprak parçasının etrafını çitle çevirip 'Bu, bana aittir' diyebilen, buna inanacak kadar saf insanlar bulabilen ilk insan, uygar toplumun gerçek kurucusu oldu" (1995, s. 135). Fakat bu; savaşların, acıların kısacası tüm felaketlerin de başlangıcı olmuştur:

\footnotetext{
"Bu sınır kazıklarını söküp atacak ya da hendeği dolduracak, sonra da hemcinslerine: 'Bu sahtekâra kulak vermekten sakınınız! Meyvelerin herkese ait olduğunu, toprağın ise kimsenin olmadığını unutursanız, mahvolursunuz' diye haykıracak olan adam, insan türünü nice suçlardan, nice savaşlardan, nice cinayetlerden, nice yoksulluklardan ve nice korkunç olaylardan esirgemiş olurdu!" (Rousseau, 1995, s. 135)
}

Locke, insanların mülkiyetlerini korumak için bir toplum sözleşmesi isterken, Rousseau, aksine insanlar arasında bir mülkiyet ilişkisi olduğu için savaşların var olduğunu ileri sürmektedir. Fakat Rousseau'nun düşüncesi de insanın özgürlüğü- 
nü yaşamak için kendi varlığını kollamayı istemesinin doğal olduğu yönündedir. İnsanın eksiklikler ve ihtiyaçlar için bir araya geldiğini düşünen Rousseau, insanı, toplum içinde kısıtlı bir varlık olarak düşünmez. Aksine insanların kendini bilecekleri çağa geldiklerinde istedikleri kararları verme; aileyle birlikte yaşama veya kendi istediği gibi bir yaşam sürme ortak özgürlüğü, Rousseau'ya göre insan doğasının bir sonucudur ve bu insanın özgürlüğüyle ilgilidir. Bu özgürlüğün birinci yasası ise, "kendi varlığını kollamaktır; insan önce kendine özen göstermekle yükümlüdür; kendini bilecek çağa geldiğinde korunmak için alınması gerekli önlemler konusunda tek söz sahibi yine kendisi olacağından kendi kendisinin efendisi durumuna gelir” (Rousseau, 1999, s. 31). Rousseau, özgürlüğü insan doğasına içkin olarak ele almaya başka bir yerde de değinir. Ona göre özgürlüğünü devreden insan, kendisinden her şeyin istendiği insandır, böyle bir insana karşı da hiçbir yükümlülük üstlenilmez. Rousseau'ya göre insanın, özgürlüğünden, insan olma niteliğinden, insanlık haklarından, hatta ödevlerinden vazgeçmesi demektir. "Her şeyden vazgeçen bir insan için herhangi bir zararın karşılanması söz konusu değildir. Böyle bir vazgeçiş insan doğasıyla bağdaşmaz; istenci özgürlüğünden tümüyle yoksun kılmak, edimlerini tümüyle töre dışına itmek demektir” (1999, s. 39).

Rahatlıkla görüldüğü üzere, Rousseau'nun özgürlük üzerine düşüncesiyle, Locke’un çıkarımları benzerlik taşımaktadır. İnsanların özgürlüklerini rahat kullanabilmesini ikisi de önemser. İkisinde de özgürlük temel olarak bireyin varlığıyla, insanın kendi kendisine sahip olabilmesiyle ilgilidir. Fakat farklılıkları toplumdaki bireyin pratikleri üzerine fikirleri ele alındığında ortaya çıkmaktadır. Bu ayrımı yapmak için önce Rousseau'nun uygar toplum eleştirisini ele almak gerekmektedir. Rousseau'nun uygar toplum diye nitelendirdiği kendi çağı nasıldır, niçin kendi çağından rahatsızdır? Uygar insanı ele alırken Rousseau, ondaki muazzam değişime değinir. Rousseau'ya göre uygar birey farklılaşmıştır: “Artık onda belirli ve değişmez ilkelerle hareket eden bir varlık yerine, Yaradan'ın damgasını vurduğu o göksel ve görkemli sadelik yerine, ancak, düşündüğünü sanan tutku ile sayıklama halindeki anlık (enterdement) arasındaki çirkin çelişme bulunur" (1995, s. 80). Peki, bu durumun nedeni nedir ve niçin insanlar bu hale gelmişlerdir? Rousseau'ya göre bunun nedeni mevcut "ilerleme" biçimidir: "İnsan türünün bütün ilerleyişi, onu, durmadan, ilkel durumlarından uzaklaştırır; bu yüzden yeni bilgiler biriktirdikçe, bütün bilgilerin en önemlisini elde etmek aracını daha fazla yok etmiş, bir anlamda, insanı incelemek zorunluluğuyla onu tanımak olanağı dışına çıkarılmış bulunuyoruz" (1995, s. 80). Yani Rousseau'ya göre, insanı incelerken, onu tanımanın imkânını kaybetmişiz. İnsan hakkındaki bilgimiz en az olandır.

Rousseau ayrıca, uygarlığın bireyi "yetkinleştirmesi” veya "olgunlaştırması"nın yıkıcı sonuçlarına değinir. Kişinin kendi yetenekleri doğrultusunda yaşantısı- 
na devam ettiği ve iş bölümünün olmadığı dönemlerde, insanın doğasına uygun yaşadığına veya insanın kendi sınırını, kendi doğasının belirlediğine dikkat çeker. Bir diğer dikkat çektiği nokta ise üretim araçlarına birilerinin sahip olmasıyla birlikte eşitliğin kaybolduğu, çalışmanın zorunluluğa dönüştüğüdür. Diğer taraftan bütün ilerlemelerin görünüşte bireyin yetkinleşmesi ve olgunlaşması, aslında ise insan türünün son evresine doğru atılmış adımlar olduğunu düşünür. Rousseau'ya göre insanlar kaba saba kulübeleriyle yetindikleri, hayvan derilerinden yaptıkları elbiselerini diken ya da kılçıkla dikmekle, kuş tüyleriyle, deniz hayvanlarının kabuklarıyla süslenmekle, vücutlarını çeşitli renklere boyamakla, oklarını yaylarını yetkinleştirmekle ya da güzelleştirmekle, keskin taşlarla birkaç balıkçı kayığı ya da bazı kaba müzik aletleri yontmakla yetindikleri sürece; kısacası, sadece bir tek kişinin yapabileceği işlere, birçok elin katılmasına gerek göstermeyen sanat ve hünerlere özenle çalıştıkları sürece doğalarının olanak verdiği kadar, doğaları gereği olabilecekleri kadar özgür, sıhhatli, iyi, mutlu yaşadılar; kendi aralarında, bağımsız bir ilişkinin zevklerini tatmaya devam ettiler (1995, s. 146). Fakat Rousseau bu hayalin bozulmasını, aşırı sahip olmayla ilişkilendirerek açıklar: "Fakat bir insanın yardımına gereği olduğu andan beri, bir kişinin iki kişiye yetecek kadar yaşama araç ve gereçlerine sahip olmasının yararlı, karlı olduğu fark edildiği andan beri eşitlik kayboldu, mülkiyet ise karıştı, çalışma zorunlu oldu; geniş ormanlar insan teriyle sulanması gereken, köleliğin ve sefaletin derhal filiz verip ekinlerle birlikte arttığı hoş ve güleç kırlar haline geldi” (1995, s. 146). Ayrıca uygar insanın mutsuzluğunu insan doğasıyla açıklamaz. İnsan karakterinin her zaman yönetimler tarafından şekillendirildiğini gözlemlediğini söyleyen Rousseau, biz sadece yönetenlerin bizi yaptığı gibiyiz ve bu yüzden kusurlarımız insan doğasından değil, aksine kötü yönetilmiş olduğumuzdan kaynaklanmaktadır der (Wokler, 2001, s. 164).

Şimdi Rousseau'nun asıl olarak Locke ile nerede farklılaştığına bakacak olursak; Locke insanın sahip olduklarını ve mülkünü özgürce kullanabilip yaşamını rahatlıkla gerçekleştirmek için toplumu ön görürken, Rousseau ancak toplum aracıl1ğıyla bu özgürlüğü elde edebileceğini ileri sürmektedir. Burada da temel ayrım mülkiyet üzerindeki tartışmalarla ortaya konabilir. Rousseau, insanlığın bütün suçlarının yeryüzünün bazı insanlarca ve diğerlerinin zararına paylaşılmasının kaçınılmaz sonucu olduğunu tartışmıştır (Wokler, 2001, s. 167). Çünkü Rousseau'ya göre özel mülk ile birlikte insanların birbirlerine bağımlı hale geldiklerini ileri sürer. Çünkü geçim araçları bir insanı diğerine mecbur kılmaktadır. Onun için özel mülk Rousseau tarafından olumlanmaz. Ayrıca Rousseau'ya göre özel mülkiyet kurumu yalnızca savaşın ortaya çıkışından sorumlu olmayıp, aynı zamanda yönetimin şekillenişinde de hesaba katılmalıdır (Wokler, 2001, s. 167). Ama Locke mülkiyet hakkını olumlar ve vazgeçilmez temel bir hak olarak kabul eder. Hatta miras yoluyla aktarılması 
gerektiğini de söyler. Diğer taraftan Locke’a göre bu hak kişinin doğuştan getirdiği iki haktan biridir: "Her insan iki hakla doğar: İlk olarak, kendi şahsına olan özgürlük hakkı, ki bunun üzerinde kişinin kendisinin özgürce devretme hakkı dışında başka hiç kimse yetki sahibi değildir. İkinci olarak, bir kimsenin, başka herhangi bir adamdan önce, onun kardeşlik hakkıyla beraber, babasının mallarına olan miras hakkıdır" (2012, s.159).

İş bölümünden sonra insanların bu sürecin doğal sonucu olarak belirli ihtiyaçlarını kendi başlarına karşılayamadıklarını göz önünde bulundurmak gerekiyor. Bu süreç insanı kendi olmaktan uzaklaştıran bir özelliğe sahiptir. Çünkü insanın ç1karı onu başka türlü davranmaya zorlamaktadır. Bu da Rousseau'ya göre şatafatlı gösteriş, aldatıcı hile, bunlarla birlikte yürüyen bütün ahlaki bozuklukları ortaya çıkarmış, öte yandan, evvelce özgür ve bağımsız olan insan, işte, önümüzde, yeni birçok gereksinmeler zoruyla bütün doğaya, özellikle de hemcinslerine boyun eğip kul olmuştur (1995, s. 151). Ayrıca insan hemcinslerine, efendi olurken bile bir manada köle gibidir. Bu durumu Rousseau şöyle örneklendirir: Zenginse, onların hizmetine, fakirse, onların yardımına bağlıdır; orta halli olmak da onu, onlardan vazgeçebilecek duruma hiç getirmez. Bu da onu, kimilerine karşı kalleş, müzevir ve düzenbaz, kimilerine karşı da çalımla buyuran, sert bir insan yapar. Onları korkutamadığı ya da kendi çıkarını onlara yararlı bir tarzda hizmet etmekte bulmadığ1 zaman, onu, gereksindiği bütün bu insanları aldatmak zorunluluğunda birakır (Rousseau, 1995, s. 151-152). En sonunda da insanı yiyip bitiren tutkudan, kendi mevkiini yükseltme hırsından çok başkalarının üstüne çıkmak gereksinmesi, bütün insanlarda karşılıklı olarak birbirlerine zarar vermek karanlık eğilimini, gizli bir kıskançlığı uyandırır. Kısacası Rousseau, bir yanda rekabet, yarışçılık öte yanda çıkar çatışmaları, hep kendi çıkarını başkasının zararına sağlamak gizli arzusunun ortaya çıktığını, bütün bu kötülüklerin, mülkiyetin ilk etki ve sonuçları olduğunu, doğmakta olan eşitsizliğin ayrılmaz maiyeti olarak görür (1995, s. 152).

Rousseau ve Locke arasındaki en büyük ayrım, insanın kendi varlığıyla, topluma dair bilinci arasındaki farkta ortaya çıkmaktadır. Buna ayrıntısıyla bakılacak olursa; Rousseau'ya göre doğa halinden uygar topluma geçiş aynı zamanda içgüdünün yerini koşullandırılmış bir aklın almasıyla mümkündür: "İnsan, doğa halinde yaşamak için gereken her şeye, içgüdüsünde sahipti; toplumda yaşamak için gerekli olanlara ise ancak işlenmiş bir akılla sahip olabilir” (1995, s. 117). Rousseau, bu şekilde insanların mevcut duruma alışmalarını sağlayan bir nevi "ideolojik aygıtlar" olarak sanatları ve bilimi de hedefe oturtur. Ona göre bilim, edebiyat ve sanatlar insanları bağlayan zincirleri çiçeklerle örter; özgür yaşamak için doğmuş görünen insanların damarlarında taşıdıkları özgürlük duygusunu söndürür. Onlara köle- 
lik hayatını sevdirir; onları uygar milletler dediğimiz topluluklar durumuna sokar (Rousseau, 2009b, s. 8). Görüldüğü üzere uygar topluma geçişi, hatta yabanıllıktan uygarlığa geçişi insanın aklının işlenmesi sonucunda mümkün olduğunu söyleyen ve bu işlenmiş aklı mümkün kılan en büyük şeyinde bilim ve sanat olduğunu söyleyen Rousseau'nun aksine Locke, Tanrı'nın, insanı, yalnız kalmanın iyi bir şey olmadığını anlayacak bir yaratık olarak yaratmasına bağlar ve Locke'a göre insan bundan dolayı topluma yönelmiştir. Ayrıca Locke'a göre, Tanrı, insana toplum içinde yaşaması için anlama yetisi ve dil vermiştir (2012, s. 53; 1980, s. 42) der. Oysa toplum içinde yaşamak Rousseau için bu kadar doğal veya Tanrısal olmaktan çok, insanın ehlileştirilmesiyle mümkün olmuştur.

Rousseau, insanın kendi çıarının peşinde gitmeye başlamasının eşitliği ortadan kaldırdığını düşünür. Aynı zamanda insanlar kendi çıkarlarını düşündüğü oranda da kötü varlıklar haline gelmişlerdir. Yani, birilerinin çıkarı diğerlerinin zararına işleyen bir süreçten bahsedilmektedir. Ona göre bir avuç zalim yüzünden açlıktan ölen insanlığın başına her şey gelmiştir. Güçlü, zayıfın idaresini ele alarak yasanın heybetli gücü ile silahlanmıştır (Wokler, 2001, s. 168). O zaman bu süreçte devleti nereye oturtacağız, mevcut kanunların işlevi ve toplumun rolü nedir?

\footnotetext{
"Zayıflara yeni bağlar zenginlere ise yeni güçler veren, doğal özgürlüğü bir daha geri dönmemek üzere yok eden, mülkiyet ve eşitsizlik kanununu ebediyen kuran, ustalıklı bir gaspa geri alınmaz bir hak payesi veren, bazı muhterislerin kârı uğruna bütün insan türünü daha o zamandan çalışmaya, kulluğa ve sefalete boyun eğdiren, toplumun ve kanunların doğuşu böyle oldu ya da böyle olmuş olsa gerektir" (Rousseau, 1995, s. 156).
}

Bu durum insan için yeni sıkıntılar da doğurmuştur: "Sayıları hızla çoğalan ya da genişleyen toplumlar kısa zamanda bütün yeryüzünü kapladılar. Artık bundan böyle evrende boyunduruksuz yaşanacak ya da herkesin kendi başının üstünde süreli olarak asılı gördüğü, çoğu zaman kötü yönetilen kılıçtan başını kurtarabileceği bir köşe bulmak mümkün olmadı" (Rousseau, 1995, s. 156). Bu anlamda bakılacak olursa Rousseau hem Hobbes hem de Locke'u hedefe oturtmaktadrr. Hobbes'un insan doğası algısına göre insan savaş yapmak zorundadır. Diğer taraftan Locke ise özel mülkü insanın doğası yerleştirerek kendi mülkünü koruma altına almayı meşru görmüştür. Oysa Rousseau'ya göre bunların hiç birinin insan doğasıyla ilişkisi yoktur, bütün bunlar insanın toplumsal olarak gelişim sürecinde ortaya çıkardığı durumlardır. Bu anlamda eşitsizlik veya devlet biçimleri de böyle anlaşılmalıdır.

Yeri gelmişken Rousseau'nun (1995) eşitsizlik hakkındaki fikirlerine de değinilmeli. Ona göre toplumda iki tür eşitsizlik mümkündür. Birisi doğal olan, diğeri ise insanların yaratmış oldukları: 
“İnsan türünde iki tür eşitsizlik görüyorum. Biri, doğa tarafından meydana getirildiği ve yaş, sağlık, bedendeki güçler ve zekâ ya da ruh nitelikleri arasındaki farklardan oluştuğu için buna doğal ya da fizik eşitsizlik diyorum. Öteki bir çeşit uzlaşmaya dayandığ1 ve insanların onaması ile kurulmuş ya da hiç değilse onlarca kabul edilmiş olduğu için buna manevi veya politik eşitsizlik adı verilebilir. Bu ikincisi kimilerinin başkaları zararına yararlandığı, örneğin onlardan daha zengin, daha itibarlı olmak ya da onlara boyun eğdirmiş olmak gibi ayrıcalıklardan ibarettir." (s. 87)

Kısacası bu yüzyıl, bütün bir toplumu ruhsuzlaştırıp kalpsiz bir dünya ortaya çıkarmıştır. Rousseau bunun daha da ileriye gideceği tedirginliğini duyumsar: "Ama ruhun bütün işlemlerinin maddileştirilmeye çalışıldığı ve insan duygularından her türlü tinselliğin çekip alınmaya çalışıldığı bu yüzyılda, yeni felsefe beğeniye olduğu kadar erdeme de zararlı hale gelmezse şaşarım" (2007, s. 71). Bu durumda Rousseau'nun şunu savunduğu rahatlıkla söylenebilir: İnsan doğal durumdan uygar topluma geçerken doğası da bozulmuştur. Ahlak ve özel mülk de bu bozulma sonucu ortaya çıkmıştır. Böyle bakıldığında örneğin hayvanların bir utanma duygusu yaşamıyor oluşunu buraya dayandırmak mantıklı görünmektedir. Ahlaksallık insan doğasından kaynaklanmamaktadır, aksine insanın toplumsallaşma sürecinde doğallığını kaybetmesiyle ortaya çıkan bir durumdur (Wokler, 2001, 169). O zaman Rousseau'nun özellikle Toplumsal Eşitsizliğin kaynağını tartıştığı kitabında (1995) uzun uzun hatta çoğu zaman bir zoolog titizliğiyle bahsetmiş olduğu, ilkel insanın diğer hayvanlara yakın olup, uygar insana ise uzak olduğu yönündeki çıkarımı buraya oturmaktadır.

Peki, Rousseau ne istemektedir, onun tüm bu eleştirileri nasıl bir toplum hayali için yapılmıştı? Bir kez daha ayrıntısıyla üzerinde durmakta fayda var: Rousseau insanın diğer canlılar içinde kendi tarihini yapan tek varlığın insan olduğu fikri üzerinde durur. Doğal durumdan uygar topluma geçtikçe artık kötü yönde doğasının bozulduğuna ve insanlığın kötüye kullanılan bu doğasından dolayı da bir topluluk içinde hayvanlardan daha perişan bir yaşam sürmekte olduğumuza inanır. Fakat Rousseau, "toplumsal yaşamımızda sınırlanmamıza, alçaltılmamıza rağmen hala kendimizi geliştirme kapasitesine sahip” olduğumuzu (Wokler, 2001, s. 170-171) ve yapay olarak oluşturmuş olduğumuz erdem ve kötülüğün üstesinden gelmek gerektiğini düşünür. $\mathrm{O}$ zaman bu kötülüğü atalarımız yapmışlarsa yeni bir toplumsal sözleşmeyle insanlık hem özgürlüğünü hem de gerçek anlamıyla eşitliği geri alabilmelidir. Peki bu nasıl bir toplumda mümkündür ve Rousseau'nun hayalinde ne vardır? Yanıtı kendi sözlerinden (1995) okuyalım:

"Doğacağım yeri seçecek durumda olsaydım, insanların yetilerinin erimi yani iyi yönetilmek olanağı ile sınırlanmış büyüklükte olan, herkes kendi yaptığı işe yettiği için kimsenin kendi yükümlü olduğu işi yapmak üzere başkalarını görevlendirmek" zorunda olmadığı bir toplumu; herkes birbirini tanıdığı için karanlık manevraların ve erdemden 
doğan alçak gönüllülüğün halkın gözünden ve yargısından uzak kalamayacağı, birbirini bilip tanımak tatlı alışkanlığının yurt sevgisini kuru toprak sevgisi olmaktan çıkarıp yurttaş sevgisi haline getireceği bir devleti seçerdim." (s. 66).

Bu durumu mümkün kılmanın yolu da insanı ilk başlardaki gibi duyar bir varlık olarak ele almaktan geçer. Rousseau'ya göre insanın düşünmeye başlamadan önce duyar bir varlık olduğu aktarılmıştı. Bu düşünce biraz daha açıklanacak olursa; Rousseau'ya göre insanı insan yapmadan önce onu bir filozof yapmak yersizdir. Onun başkalarına karşı görevleri, sadece gecikmiş bilgelik dersleri tarafından emredilmiş değildir. İnsan içten gelen acıma dürtüsüne karşı koymadıkça başka bir insana hatta duyarlı herhangi bir varlığa asla fenalık yapamaz; Rousseau bunun istisnasının kendi varlığının korunması söz konusu olduğu zaman kendini tercih etmesini gösterir. İnsanın akıllı varlık olmasından çok duyarlı yani hisseden bir varlık olmasının daha önemli olduğunu söyleyen Rousseau, aslında insan hemcinslerine hiçbir fenalık yapmamak zorundaysa, bu, onların akıllı varlıklar olmalarından çok duyarlı varlıklar olmalarından ileri gelir demektedir. Çünkü Rousseau'ya göre bu duyarlılığın niteliği hayvanda ve insanda ortak olduğu için, bunlardan birine, en azından, öteki tarafından kötü muamele edilmemek hakkı tanınmalıdır (1995, s. 83-84). İşte Rousseau, insanın gerçek gereksinmesinin ve görevlerinin temel ilkelerinin insan soyundan başlatılan bu incelemesinin insanlar arasındaki manevi eşitsizliğin kaynağı veya politik yapının gerçek temellerinin bu fikir etrafında kurulması gerektiğini söyler (1995, s. 84).

Peki Rousseau özgürlüğe nasıl bakmaktadır, Rousseau'cu bir toplumda özgürlük nasıl gerçekleşir? Ona göre özgürlük, insanın her canının istediğini yapmasından çok, insanı bir şey yapmaya zorlayan koşullarda, kendini bu şeyi yapmama konusunda özgür hissedebilmesi durumudur: "İnsan için özgürlüğün, istediğini yapmaktan çok istemediğini yapmamak olduğuna her zaman inanmışımdır" (1944, s. 84-85). Birçok bireyin olduğu bir toplumda böyle bir olanak mümkün müdür, insanlar birbirleriyle çatışma içine girerler mi ve girerlerse bu sorun nasıl ortadan kaldırılır? Bu anlamda Rousseau (1995) özel çıkarla genel çıkarın uyuşmayabileceğini kabul eder:

"Gerçekte de her bireyin, insan olarak özel bir istenci olabilir ve bu istenç, onun yurttaş olarak katıldığı genel istence uymayabilir ya da aykırı olabilir. Özel çıkarı, onu ortak çıkardan çok ayrı bir yöne çekmek isteyebilir; kendi saltık ve saltık olduğu için de bağımsız varlığı, ortak davaya olan katkı borcunu, ona, karşılıksız bir yardımmış gibi gösterebilir; yardımın yapılmamasının ortak davaya vereceği zararın, yardımı yapması durumunda kendisinin uğrayacağı zarardan daha az olduğunu düşünebilir; ve devlet denen tüzel kişiyi, bir insan olmadığı için, us ürünü bir varlık olarak gördüğünden, uyrukluk ödevlerini yerine getirmeksizin uyrukluk haklarından yararlanabilir." (s. 51) 
Böyle bir durumda ne yapılması gerektiğini tartı̧̧ırken Rousseau, insanın ikna edilmesinden bahseder. Fakat bunu kötü bir durum olarak değil de insanın özgür olmaya zorlanması olarak görür. Çünkü eğer her isteyen istediği gibi davranırsa bu durumun yaygınlaşması siyasal birlikteliğin yıkımına neden olacak bir haksızlık ortaya çıkaracaktır. Rousseau'ya göre böyle durumlarda, toplumsal antlaşmanın boş bir söz olarak kalmaması için, genel istence uymayı reddeden her kim olursa olsun, tüm toplumca saygıya zorlanmasını sağlayacak gücü öteki ortaklara veren yükümlülük, antlaşmada örtülü biçimde vardır. Rousseau için bunun anlamı ise, o kimsenin özgür olmaya zorlanmasıdır çünkü bu koşul, tüm yurttaşları yurda mal etmekle onları her çeşit kişisel bağımlılıktan korur; siyasal düzeneğin hilesini ve hünerini oluşturduğu gibi yurttaşlık yükümlülüklerini de yalnız o meşru kılar ki, onsuz, bu yükümlülükler anlamsız ve zorbaca olurdu ve çok büyük kötülüklere uğrardı (1999, s. 51). Yani Rousseau, sözleşmeden doğan hakkıyla özgür olan kişinin, yine aynı hakka dayanarak genel istence ters düşemeyeceğini söylemektedir. Bu görüş Locke'un düşüncesiyle de benzerlik göstermektedir. Locke'un, yukarıda insanın iki hakla doğmuş olduğunu söylediğine değinilmişti. Hatırlanacağı üzere, ilk hak olarak Locke, insanın kendi şahsına olan özgürlük hakkından bahsetmekteydi. İşte Locke'a (2012) göre bu hakka dayanarak:

"Bir insan herhangi bir hükümete tabi olmaktan, onun hakimiyeti altındaki topraklarda doğmuş olsa da, doğal olarak özgürdür. Fakat eğer o doğduğu ülkenin yasal yönetimine itaati reddediyorsa, o aynı zamanda onun yasalarıyla elde ettiği hakkından ve ona atalarından kalan mülklerinden de, eğer o sözleşmeyle oluşturulmuş bir hükümetse, vazgeçmelidir." (s. 125)

Locke da Rousseau'ya benzer biçimde insanın özgürlüğünü aldığı hakka dayanarak, o hakkın kaynağı olan hükümetin genel yasalarıyla ters düşemeyeceğini düşünür. Rousseau'nun özgürlük anlayışı bu bağlamda iki temele oturur, her şeyden önce sadece yasaya itaat değil, yasamanın da kaynağının bireyde olduğu fikri ve özgürlüğün erdemin koşulu ya da sonucu olmadığı gibi bizatihi erdem de olmadığ1 yönündeki anlayış (Strauss, 2011, s. 317). Rousseau, ancak ve ancak bütün uyrukların aynı zamanda egemen olduğu bir devlette, devletin özgürlüğün bir aracı olarak hizmet edebileceğini ve ancak o zaman halkın gerçek anlamda kendi kendini yönettiğinin söylenebileceğini savunur (Wokler, 2001, s. 172). Bu anlamda, bu tür bir yönetimde Hobbes'un kurgusunda olduğu gibi veya ismi anılacak olursa Bodin'deki gibi egemenlik ilkesine dayandırdıkları devletin başındaki kişinin üstün gücü söz konusu değildir. Yönetim hem yönetene hem de yönetilene eşit uygulanır. Fakat Strauss'un hatırlatmasını akılda tutmak da gerekebilir: Rousseau, en iyi toplumun bile bir tür kölelik olduğuna inanmıştır (Strauss, 2011, s. 292). 


\section{Sonuç}

Platon ve Aristoteles, insanların doğaları gereği tek yönlü gelişebileceğini ileri sürmüş ikincisi birincisini insanların doğaları gereği siyasal hayvan oldukları savıyla ileriye taşımış ve en nihayetinde birilerinin doğaları gereği yöneten birilerinin ise yönetilen olması gerektiğini savlamıştır. Aristoteles geleneğini sürdüren gerek İslam düşüncesi içindeki Farabi gerek batı düşüncesinde Aquinas kimilerinin doğası gereği daha farklı olduğunu ileri sürmüşlerdir. Aquinas, insanların rasyonel ve siyasi canlılar olduğu için ahlaki bir ilke de geliştirebildiklerine değinerek insan doğası tartışmasını farklı bir noktaya taşımıştır. Machiavelli ise insanların doğrudan kendi çıkarlarına yöneldikleri için onları yönetenlerin dikkatli ve buna göre davranmaları gerektiğini savunmuştur. İnsanın asosyal bir varlık olduğunu ileri süren nadir düşünürlerden birisi Hobbes'tur. Yine Hobbes'a göre insanlar sadece kendilerini korumanın peşinde oldukları için bu insanlar arasında sonsuz bir savaşımın olacağ1 anlamına gelmektedir ve bunu ortadan kaldırmanın yolu tüm topluma hükmeden bir yöneticinin varlığıdır.

Locke ve Rousseau ise siyasal düşünce tarihinde, insan doğası ve toplum anlayışı olarak kendinden önceki bir çok düşünürden farklı bir bakış açısı sergilemektedir. Artık özel mülk meşru bir zeminde düşünülmüş, insanların topluluk halinde yaşamalarının nedeni daha dünyevi temellere bağlanarak ele alınmış, siyasal egemenin dışında bir sivil toplumun insanlar arasında çatışmaların ortadan kaldırılmasında yardımcı olacağı fikri ortaya atılmıştır.

Siyaset düşünce tarihinde kendi sitemini bir insan anlayışı üzerine kurmayan düşünür yok gibidir. Bir düşünürün insan doğasına dair çıkarımınıda koşullandıran en büyük etken yaşamakta olduğu çağın kendisidir. Bu anlamda Locke ve Rousseau'ya baktığımızda ikisinin de kendi çağında yaşanmakta olan dönüşümden etkilendiği görülmektedir. Fakat yaşanmakta olan dönüşümün filozofun dünyasına olduğu gibi yansıdığını söylemek yanlış olacaktır. Bu anlamda Locke için mülk edinme bir doğal hak olarak görülürken, Rousseau için toplumdaki eşitsizliğin ve nispeten karmaşanın kaynağıdır.

Locke, insan doğasının eğitimle biçimlenebileceğine atıf yapar. Fakat bu insanda olmayan bir şeyin onun elde etmesine olanak verecek bir şey değildir. Eğitim insanın yol bulmasını sağlar. Ayrıca insan toplum içinde yaşamaya yazgılıdır, çünkü Tanrı'nın ona vermiş olduğu akıl sayesinde o bunun daha iyi olduğunu anlar. Aynı zamanda kendi türünden varlıklarla yaşaması zorunluluğu ve eğilimi de insana, Tanrı tarafından verilmiştir. İnsan, ayrıca doğuştan ahlaki ilkeler getirmez. İnsanın kendisine kılavuzluk edecek olan şey yine kendi aklı olmalıdır. Bu anlamda Locke devleti ve toplumu insana kölelik ilişkisi yaratan kurumlar olarak görmez. Toplum- 
da insanların ilişkisi özgür ve erdemli insanların ilişkisi gibi olmalıdır. Bu anlamda toplum, insanın bütün mülkiyetlerini -ki buna yaşam hakkı da dâhildir- yaşayabilmesi için olanaklar sunar. Eğer toplum olmasa insanın sahiplikleri sürekli tehdit altında olacaktır. Bundan dolayı insanın sahiplikleri üzerinde hareket etmesinin olanağını da toplum sağlar.

Rousseau'ya baktığımızda ise insanın akılla ön plana çıan bir varlık olmaktan çok duyar bir varlık olduğu fikri ön plana çıkmaktadır. Rousseau doğa karşısında insanın hayvan gibi edilgen değil aksine aktif bir varlık olduğunu düşünür. İnsan doğada düşmanlıklar içinde olsa da bu bir savaş hali değildir. İnsanları bir araya getiren şey ise ihtiyaçları ve gereksinimleridir. Fakat Rousseau burada bir ayrıma gider; insanlar bir araya gelirler ama toplum içinde yaşamaları ne doğalarından kaynaklanır ne de aslında gereklilikler kalkarsa buna zorunludurlar. Aksine insanlar toplum içinde yaşamak için uyumlu hale getirtilirler. İnsanlar doğuştan ne kraldırlar ne de köle. Bundan dolayı birilerinin yöneten diğerlerinin yönetilen olması gibi bir şey doğal karşılanamaz. Böyle olduğu için de insanlar topluma belirli haklarla katılırlar ve bu hakka dayanan her eylem de o toplumun kendisiyle ters düşemez. Rousseau'nun Lockecu toplum anlayışına en çok yaklaştığı yer bu düşüncedir. Çünkü Locke da insanın özgürlüğünün dayandığı hakkın genel istençle ters düşmesini olumlamaz. 


\title{
Human Nature and Society in the Philosophy of John Locke and Jean Jacques Rousseau
}

\author{
Olkan Senemoğlu
}

\section{Introduction}

The Enlightenment was an age during which many developments took place, among them strong breaks with the past and the reinterpretation of existing institutions. This age was separated from the previous ones by the development of a new society, nature and human perception. Above all, the expression "Man is the measure of all things" was internalised by re-interpretation. Thus, scholastic and dogmatic beliefs were ignored while humans and preferences were given prominence. The idea of enlightenment itself was gradually criticised, the idea that man is born with a certainty of believing in God came was criticised, as well. Of course, one can find ideas about human nature and society in the history of all political philosophy; however, this age differed from others in many aspects.

Until John Locke (1632-1704) and Jean Jacques Rousseau (1712-78), many philosophers had come up with various definitions of human nature and society. These theories generally explained human nature as being based on a truth other than humanity. This worldview which began to break down with Thomas Hobbes (1588-1679) has become clearer with Locke and Rousseau. Because the Age of Enlightenment adopted an anthropocentric approach, private property thus began to be worked through. Along with these new views, different views about human nature also began to come forward. This study, in general, focuses on Locke and Rousseau's concepts of human nature and society, which differ from those of the previous philosophers. In examining the fundamentals of thought about human nature, what they sought to establish as a society and governance is also a question of debate. 
Many authors have discussed the views of these two philosophers. And yet the common point of such studies is quite often the authors' creation a focal point in their systems and the subsequent deepening of their debate at that point. As will be seen below, these studies have ignored the main axis of many of their concepts, either by excluding the human nature debate or by mentioning it only briefly because they want to focus on their own "concepts". This study focuses on how Locke and Rousseau's conception of the human being, human nature and society influenced their political opinions in general, and other concepts such as contract, rights, ownership and management in particular. The study's main argument is that their distinctive systems will be misunderstood if one does not correctly perceive their conception of human nature and society.

\section{John Locke's Conception of Human Nature and Society}

The distinctness of Locke, who gave a new impulse to the history of thought through his essay on Man's Comprehension Ability (Locke, 1999b), lies in the specific inductive method he developed as an attack on man's innate propriety to the world and on $a$ priori knowledge theories, and that man comes into the world with innate ideas. With his inductive method, Locke formulated a new understanding of the experimental materialism proposed by Hobbes and Pierre Gassendi (1592-1655) in particular.

Locke, like many other philosophers, sees man as a social creature. However, his emphasis is directly related to a belief in God: "God, who created mankind as a social being, granted him not only the tendency and necessity to live with his own kind, but also the tongue which is the strongest social tool and bond" (Locke, 1999b, pp. 11)." Thus Locke seems to have explained man's ability to speak by referring to God. As will be seen below, this conception differs from that of Rousseau.

Locke's human perception is that people exist with the attributes that nature has given them, but that these can be transformed through education. According to him, one who does not act wisely will never choose the right way, and one who has a sick and weak body will never make any progress. Even if a person has a certain congenital structure, education can change that. Locke holds that educating a person seems to be like touching a river: "A gentle touch to the sources of some rivers directs the water to the water trenches flowing in quite different directions and this touch leads them to different orientations and eventually far distant places" (Locke, 2004, p. 13). Although man is assumed to have been shaped by education and his ability to understand is considered more advanced, Locke tells us about unchangeable character traits, referring to having two arms and two legs given by God, which 
is also unchangeable: "We should not hope to completely change children's unique mood, to make a joyful person serious, nor a melancholy one alive. God has set certain character traits in people's minds like their shapes" (Locke, 2004, p. 51). He writes that this situation can be corrected, but only to a very limited degree: "It is too difficult to completely change and to reverse them" (Locke, 2004, p. 51).

Briefly, Locke states that a person's presence in a community is based upon two reasons: (1) God has already created man as a worthy being who can feel that it is bad to be alone and (2) that man has seen that he can only fully exercise his rights within a community. Yet here, the question of what the state's role will be emerges. While Hobbes argues about sacrificing man's freedom to overcome the confusion in society and the risk of anarchy in order to build an authority, Locke dreams of a limited authority in which man's freedom is not restricted and, at the same time, will never degenerate into arbitrariness and despotism. Hence, authority is limited by "natural law" and the people's consent. Natural law, which imposes eternal and complete tasks on all people and therefore acts as a law, is to be emphasized here.

\section{Jean-Jacques Rousseau's Conception of Human Nature and Society}

Rousseau, who puts forward ideas as a reaction to the notion of civilization, the defenders of reason and the destruction caused by the Age of Enlightenment (even though he is a philosopher of this age), begins his Social Contract - which is regarded as one of his most important works - with Vergilius' statement "foederis aequas Dicamus leges" (Vergilius, 1998) and then his own question: "Can there be a legitimate and secure administration when we accept people as they are, laws as they might be?" (Rousseau, 1999, p.27). This question concerns the possibility of good governance based on equality and freedom. For Rousseau, freedom and free will are fundamental issues. Therefore, he naturally criticizes everything that legitimizes the conditions that restrict human freedom: "People are born free, but they are stranded everywhere, and even those who think they are masters of others are not less slaves than them, I do not know how this change from freedom to slavery has occured, who can legitimate it?" (Rousseau, 1999, p. 29). In this context, his conceptualization of human nature involves both what must be in accordance with human nature and what could or would be if civilization did not destroy it (Goyard-Fabre, 2013, p. 48). Rousseau therefore fights civilization and reveals the contradictions of the social system, the injustices of civilized man and the inequities and excesses of the institutions (Goyard-Fabre, 2013, p. 49). 
According to Rousseau, an animal has instincts and a human has the free will to choose or reject. Thus an animal cannot get away from what rules it, even if doing so would be more beneficial to do so, whereas a person can often go away, even if it is not good for him. So a pigeon dies starving at the head of a leash full of the best flesh, and a cat at the pile of fruit or grain, although each of them would survive if they tried to feed on the food they had despised (Rousseau, 1995, pp. 102). Rousseau believes man has the free will, while animal does not. And the most important thing that distinguishes human beings from animals is the former's consciousness of self.

Locke contends that a human would want to participate in a society in order to protect his wealth, life and liberty. So actually, he thinks that man is self-sufficientand yet sees the necessity of establishing peace with a contract because is also constantly threatened. Rousseau, however, refers to the fact that society is formed by bringing together people who do not already get along with each other. According to Locke, man has chosen to live in a community because God has created man as a creature who understands that being alone is not a good thing in his own mind. But in Rousseau's mind, it is weakness that makes man sociable.

The greatest distinction between Rousseau and Locke arises over man's consciousness of his own being and collective consciousness. In more detail, Rousseau contends that the transition from nature to civilized community is also possible through a conditioned wisdom replacing instinct: "To live in nature man possesses everything instinctively he needs, but if he is to live in society he can only have what he needs with a cultivated wisdom." (Rousseau, 1995, p. 117). In this way, he sees the arts and cognition as targets, as a kind of "ideological devices" that enable people to get used to the present situation. According to him, science, literature and arts cover the chains connecting people with flowers; it extinguishes the feeling of freedom carried in the veins of people who appear to be born free. He makes them love slavery and puts them in the position of the communities that we call civilized nations (Rousseau, 2009b, p. 8).

Contrary to Rousseau, who says that the transition to civilization, even the transition from savagery to civilization, is possible if one cultivates his mind and that the greatest thing that makes this possible is art and science, Locke believes that God created man as a being who can understand that is not good to be alone and that this accounts for people's orientation to community. He also says that God has given people the ability to understand and speak so they can live in society (Locke, 2012, p. 53, Locke, 1980, p. 42). However, living in a community is possible only by taming the human. 


\title{
Result
}

Locke refers to the fact that human nature can be shaped by education. But this is not to say that education will allow a human to obtain anything with which he has not been endowed. Education helps people find their way. Moreover, man is destined to live in society for he understands that it is better for him to do so, thanks to the intellect that God has given him. At the same time, the obligation and tendency to live with beings of his own kind is given by God. Moreover, as man is not endowed with moral principles, he must be guided his own wisdom. In this sense, Locke does not regard the state and society as institutions that create a bond of slavery for man. The relationship of people in society must be like the relationship of free and virtuous people. In this sense, society offers opportunities for people to experience all of their possessions - including the right to life. If there is no society, the ownership of the person will be constantly threatened. That is why society provides the possibility of people to act on their ownership.

As for Rousseau, what stands out is man's sensitiveness rather than his wisdom. Rousseau thinks that in the face of nature, man is not a passive but rather an active being. Although human beings exist in mutual hostility when living in nature, this is not a war. What brings people together is their needs and requirements, and so people come together. But life in society is not caused by their nature, nor is it necessary to live together if the requirements actually disappear. On the contrary, people are brought into conformity by living in society. As they are born neither as slaves nor as masters, it is therefore unnatural for there to be any rulers and ruled ones. Thus people participate in society with certain rights, and every action based on this right cannot be in conflict with the community itself. This is where Rousseau comes closest to Locke's conception of society. Locke also does not admit that the right of man's freedom is contrary to the general will.

\section{Kaynakça | References}

\author{
Ağaoğulları, M. A. (2006). Ulus-Devlet ya da Halkın Egemenliği. Ankara: İmge Kitabevi. \\ Aristoteles. (1985). Metafizik (C. 1) (A, Arslan, Çev.). İzmir: Ege Üniversitesi Basımevi. \\ Aristoteles. (1997a). Fizik. (S. Babür, Çev.) İstanbul: Yapı Kredi Yayınları. \\ Aristoteles. (1997b). Nikomakhos'a Etik. (S. Babür, Çev.) Ankara: Ayraç Yayınevi. \\ Aristoteles. (1975). Politika. (M. Tuncay, Çev.) İstanbul: Remzi Kitabevi. \\ Arnhart, L. (2005). Siyasi Düşünce Tarihi: Plato’dan Rawls'a. (A. K. Bayram, Çev.) Ankara: Adres Yayınları. \\ Augustine, S. (1999). İtiraflar. (D. Pamir, Çev.) İstanbul: Kaknüs Yayınları. \\ Bacon, F. (2006). Denemeler (6. Baskı) (A. Göktürk, Çev.). İstanbul: Yapı Kredi Yayınları. \\ Bacon, F. (2012). Novum Organum; Tabiatın Yorumu ve İnsan Alemi Hakkında Özlü Sözler. (S. Önal, Çev.) İstanbul: Say Yayınları. \\ Farabi. (2001). El Medinetü’l Fazıla. (N. Danışman, Çev.) Ankara: Milli Eğitim Bakanlığı Yayınları.
}


Farago, F. (2013). Modern siyaset Kuramı: Hobbes ve Locke. J. Russ v.d. (Ed.), Felsefe Tarihi: Modern Dünyanın Yaratılması içinde (2. Baskı, C. 2) (İ. Yerguz, Çev.). İstanbul: İletişim Yayınları.

Hobbes, T. (2007). Leviathan; veya Bir Din ve Dünya Devletinin İçeriği, Biçimi ve Kudreti. (6. Baskı) (S. Lim, Çev.). İstanbul: Yapı Kredi Yayınları.

Hobbes, T. (2014). Elemente Philosophica De CIVE, Yurttaşlık Felsefesinin İlkeleri (2. Baskı) (C. D. Zarakolu, Çev.). İstanbul: Belge Yayınları.

İbn-i Haldun. (2004). Mukaddime (C. 1) (H. Kendir, Çev.). İstanbul: Yeni Şafak.

Kriegel, B. (2010). Klasik Siyasi Felsefe Metinleri. (Z. İlkgelen, Çev.) İstanbul: İletişim Yayınları.

Locke, J. (1999a). İnsanin Anlama Yetisi Üzerine Bir Deneme, I.-II. Kitap. (M. D. Topçu, Çev.) Ankara: Öteki Yayınevi.

Locke, J. (1999b). İnsanın Anlama Yetisi Üzerine Bir Deneme, III.-IV. Kitap. (M. D. Topçu, Çev.) Ankara: Öteki Yayınevi.

Locke, J. (2004). Eğitim Üzerine. (A. Uğur, Çev.) Ankara: Yeryüzü Yayınevi.

Locke, J. (2010). Hükümet Üstüne İkinci Tez. (A. Doğan, Çev.) İzmir: İlya İzmir Yayınevi.

Locke, J. (1980). Second Treatise of Government (s. 66). İndianapolis: Hackett Publishing Company.

Locke, J. (2012). Yönetim Üzerine İkinci İnceleme; Sivil Yönetimin Gerçek Kökeni Boyutu ve Amacı Üzerine Bir Deneme (2. Baskı) (F. Bakırcı, Çev.). Ankara: Ebabil Yayınları.

Machiavelli, N. (1994). Prens (2. Baskı) (N. Güvenç, Çev.). İstanbul, Anahtar Kitaplar Yayınevi.

Platon. (1975). Devlet (3. Baskı) (S. Eyüboğlu ve M. A. Cimcoz, Çev.). İstanbul: Remzi Kitabevi.

Platon. (1998). Yasalar (2. Baskı, C. 2) (C. Şentuna ve S. Babür, Çev.). İstanbul: Kabalcı Yayıvvi.

Rousseau, J. J. (1944). Yalnız Gezerin Hayalleri. (R. N. Darago, Çev.) İstanbul: MiV.

Rousseau, J. J. (1995). İnsanlar Arasındaki Eşitsizliğin Kaynağı (5. Baskı) (R. N. İleri, Çev.). İstanbul: Say Yayınları.

Rousseau, J. J. (1999). Toplum Sözleşmesi Ya da Siyasal Tüze Üzerine (2. Baskı) (A. Erenuluğ, Çev.). İstanbul: Öteki Yayınevi.

Rousseau, J. J. (2007). Melodi ve Müziksel Taklit İle İlişki İçinde Dillerin Kökeni Üstüne Deneme. (Ö. Albayrak, Çev.) İstanbul: Türkiye İş Bankası Kültür Yayınları.

Rousseau, J. J. (2009a). Emile ya da Eğitim Üzerine. (İ. Yerguz, Çev.) İstanbul: Say Yayınları.

Rousseau, J. J. (2009b). Bilimler ve Sanatlar Üstüne Söylev. (S. Eyüboğlu, Çev.) İstanbul: Türkiye İş Bankası Yayınları.

Ruby, C. (2012). Siyaset Felsefesine Giriş. (A. U. Kılıç, Çev.) İstanbul: İletişim Yayınları.

Goyard-Fabre, S. (2013). Rousseau'nun Yapıtlarında Felsefe ve Siyaset. A. Baudart, vd. (Ed.), Felsefe Tarihi: Aklın Zaferi içinde (2. Baskı, C. 3) (İ. Yerguz, Çev.). İstanbul: İletişim Yayınları.

Strauss, L. (2011). Doğal Hak ve Tarih. (M. Erşen ve P. Onur, Çev.) İstanbul: Say Yayınları.

Tannenbaum, D. ve Schultz, D. (2008). Siyasi Düşünce Tarihi: Filozoflar ve Fikirleri (4. Baskı) (F. Demir, Çev.). Ankara: Adres Yayınlar1.

Wokler, R. (2001). Jean Jacques Rousseau: Ahlaki Çöküş ve Özgürlük Arayışı. B. Redhead (Ed.), Siyasal Düşüncenin Temelleri içinde (s. 161-179) (M. Türkkahraman, Çev.). İstanbul: Alfa Basım Yayım. 
